\title{
CORPORATE GOVERNANCE AND DIVIDEND STRATEGY: LESSONS FROM AUSTRALIA
}

Hussein Abedi Shamsabadi*\#, Richard Chung, Byung Min*

\begin{abstract}
Purpose: The purpose of this paper is to empirically investigate the effects of corporate governance on the dividend payout in Australia where dividend payout remains high and the corporate governance system has been strengthened.

Design/methodology/approach: A self-constructed governance index from 2001 to 2013 is used to test the effect of corporate governance on dividend payouts. Two versions of the indexes, and the traditionally emphasized governance elements, such as board structure, are also used for the robustness checks. A random effect panel Tobit model is employed to test the factors influencing dividend payout decision.

Findings: Estimation results report a positive effect of governance, combined with firm size and profitability, on dividend payouts. In contrast, financial distress and the GFC have a negative effect on dividend policy. Finding of further examinations imply that the positive effect of governance is attenuated by growth opportunities, while intensified by the franked dividend.
\end{abstract}

Originality/value: In this paper, the sample period and the governance index, respectively, are the longest and the most comprehensive among existing studies in the case of Australia. This paper also combined the traditional governance-dividend theme with corporate tax, particularly the unique franked dividend tax system.

Keywords: Corporate governance, Dividend policy, Corporate governance index, Panel data, Australia.

Paper Type: Research Paper

\#Corresponding author: Griffith Business School, Griffith University, 170 Kessels Rd, Nathan, Brisbane, QLD 4111, Australia. Email: hussein.abedishamsabadi@griffithuni.edu.au; Tel: +61 411529100 


\section{Introduction}

Corporate governance and dividend payout are clearly related but what is not clear is the nature of this relation. Does dividend substitute for, complements, or is it the outcome of corporate governance? The importance of board characters such as board size, independence, CEO duality, audit or other committees on dividend payout have been acknowledged by previous studies. The importance of governance on dividend policy at firm-level is not a new area, and has been studied mostly in the US and Europe. However, this finding cannot be generalized without qualification to Australia. The case of Australian dividend policy is interesting because it differs substantially from that of the US and the UK, although its governance system adopted the same framework as the traditional Anglo-Saxon system. In particular, corporate dividend strategy has changed remarkably since the late 1980s, when Australia introduced the franked dividend policy. Since then, the average payout ratio of Australian firms has maintained a substantially higher level.

Researchers on corporate governance have associated the importance of governance with corporate dividend policy. Based on extensive reviews of existing studies, Shleifer and Vishny (1997) conclude that the ultimate goal of corporate governance is to protect minority shareholders. Dividend payments can be used to reduce the existing conflict between corporate insiders (such as controlling shareholders and managers) and outsiders (such as minority shareholders) or to decrease the agency conflict between majority and minority shareholders (Jensen, 1986). Well-functioning corporate governance is required to mitigate the agency problem that arises from the separation between ownership and managerial control. Given the limited ownership of a hired manager, the marginal benefits of pursuing private benefits at the expense of shareholders are greater than the marginal costs to the manager in limited liability companies. The agency theory implies the need to distribute "free cash flow" that otherwise would be exploited by a manager's private consumption or spent on 
unprofitable projects (Easterbrook, 1984; Jensen, 1986). In addition, this theory illustrates that the distribution of free cash flow creates an opportunities for firms to be scrutinized by capital markets to the extent that the more dividend payout leads to larger issuance of new shares. Dividend payout can be used as one of the main means of distributing the free cash flow and reducing agency costs. The positive role of corporate governance on propensity to distribute higher dividend has been supported by Jiraporn et al. (2011) in the US.

La Porta et al. (2000) capture the importance of the governance role of dividend and show that shareholders' rights are considered higher in Australian firms in comparison with those in other countries. Their study presents two important models that can help in explaining dividend policy: the outcome model and the substitute model. The "outcome model” explains that effective pressure by minority shareholders can force insiders to pay out profits. The "correct” dividend policy is the outcome of governance system because the manager of firms with a better corporate governance regime is more likely to act in the interests of the shareholders and pursue value-maximizing policies, such as dividend payouts. Similar finding were likewise found in Adjaoud and Ben-Amar,(2010) and Mitton (2004). The "substitute model" on the other hands predicts that insiders (managers) can use dividend payout to establish a reputation for appropriate treatment of minority shareholders. Therefore, in countries with weak investor rights, managers pay higher dividends. The substitute model was also found in the study of Crutchley and Hansen (1989).

Australia has strengthened corporate governance, particularly since the activity of the ASX Corporate Governance Council (2003)[1]. Similar to the introduction of the 2002 Sarbanes-Oxley (SOX) Act in the US, corporate scandals such as the collapse of the large insurance company, HIH (2001), have drawn more public and academic attention to the governance issue in Australia. While most corporate governance elements are similar to the cases of the US and the UK, the Australian governance system allows investors to influence 
more managerial decisions (Nenova, 2003). For example, investors can influence directors or CEO nominations, and the ability to transfer assets to related parties at nonmarket terms or perquisites consumption at the expense of the firm. As such, it is interesting to examine the association of corporate governance with dividend payments in Australia.

Despite the Miller and Modigliani (1961) irrelevance proposition, corporations and shareholders have regarded dividend policy as an important component. The more dividend payouts become a strategic decision, the greater the importance of the directors (BOD) and corporate governance. This is because a good structure of BOD has better monitoring power on the financial decisions of the company.

Another reason for the selection of Australian companies in this study is that they have adopted the liquidity-test basis model for distribution of dividends since 2001, which is different from the distributable profit model used in the UK, Malaysia and Singapore. According to the liquidity-test basis model, Australian corporations cannot pay dividends unless all the following requirements are met: the company assets exceed its liabilities immediately before the declaration of dividend and the excess is sufficient for dividend payment; the amount of dividend is reasonable and fair for the company's shareholders as whole; and the dividend payment does not materially prejudice the company's ability to pay its creditors. Dividend payment can materially prejudice the ability of the company to pay its creditors if it results in insolvency. The liquidity-test, therefore, emphasizes the role of governance regime especially company directors in preventing insolvent trading upon the payment of dividends. Following the amendments of the Australian Corporation Act 2001, the role of the BOD is strengthened to prevent insolvency[2].

Australian shareholders do not pay separate tax on the money they receive as dividends. Investors in Australia can use franked dividends to lower or to offset the amount of total tax paid. This is a major difference of the Australian franked dividend system from other major 
developed economies such as the US and Japan, where the company pays corporate tax on their profits and shareholders pay personal tax when they receive dividends. As a result of this franked dividend tax system, Australian shareholders are expected to receive higher dividends than those in the US and Japan.

Most previous studies in Australia used single variables to test the effect of corporate governance on dividend payout policy (Yarram and Dollery, 2015). However, one size does not fit all, especially in the context of corporate governance, as claimed by Gompers et al. (2003). A self-constructed governance index is created to examine the effect of governance on dividend payouts. However, in contrast with the current paper, previous studies examined the effect of governance index on firm performance (Linden \& Matolcsy, 2004), information disclosure (Beekes and Brown, 2006), and corporate social responsibility (Chan et al., 2014). Yarram (2015), as an exception, examined the relationship between governance index and dividends in Australia. However, these studies, including Yarram (2015), have used the existing Horwath index, which is based on some selected companies. Another potential limit of this index is that it covers financial and utility companies whose financial statements have different structures and are highly regulated. Furthermore, and in contrast with existing studies, the governance index developed in this study is comprehensive because it covers the board function, audit committee, nomination committee, and remuneration committee. Further, the governance index developed in this paper is more comprehensive because it is based on a long-horizon approach and is developed based on the variables that have positive effects on dividend payouts. In particular, this study develops a number of governance indices to increase the robustness of the estimations.

The span of the data in this study is longer than any of the other existing studies in Australian corporate governance and dividend policy. The data commences in 2001, when the Best Corporate Governance was introduced, and runs to 2013. This enabled further 
examination of governance effect on dividend payouts during and after the Global Financial Crisis (GFC). Examining this issue of governance and dividend policy during the financial crisis is important (Fama and French, 2001).

For these reasons, we expect our study to add values to existing studies on corporate governance literature and dividend policy researches. In particular, the self-constructed corporate governance index using the longest time frame and the largest samples in Australia differentiates our study from existing studies that focuses largely on one element of governance system and/or governance index using small samples. In addition to the classic investigation of the effect of governance on dividend payouts, our paper also analyses the issue combined with the Australian unique tax system of the franked dividend.

The empirical hypotheses are developed in the following section. Section 3 introduces the estimation model, followed by Section 4, which describes the data and the governance index. Estimation results and the discussion are contained in Section 5. Section 6 reports the robustness check. Section 7 contains conclusions.

\section{Literature review and hypothesis development}

The free cash flow argument proposed by Jensen (1986) and Easterbrook (1984) illustrates that retained cash without dividend distribution may create the agency problem. Managers strongly prefer not to pay dividends because dividend payouts reduce the amount of cash subject to managerial discretion (Jensen, 1986). The outcome model of La Porta et al. (2000) shows that dividends are paid because minority shareholders pressure corporate insiders to distribute cash. Shleifer and Vishny (1997) suggest that the goal of corporate governance is to protect (minority) shareholders. A positive relationship between corporate governance and dividend payouts exists because companies with stronger governance mechanisms are better at monitoring their managers; therefore, managers are less likely to use the money for their 
personal benefits, and as a result they pay higher dividends (Smith, 1992; Farinha, 2003). Additionally, companies with stronger governance mechanisms have better firm performance, which can result in higher dividend payouts. Mitton (2004) and Francis et al. (2011) empirically demonstrated this positive association. The present study therefore summarizes these predictions in the first testable hypothesis:

H1: Firms with stronger corporate governance will have higher dividend payouts. Furthermore, the life cycle theory (DeAngelo et al., 2006; Grullon et al., 2002) implies that mature firms pay greater dividends than growing firms. Damodaran (1999) also states that a firm's dividend policy tends to follow the life cycle of the firm. The life-cycle theory states that a good payout policy is driven by the firm's need to distribute its free cash flow along the corporate life cycle (DeAngelo and DeAngelo, 2006). During the mature growth stage, firms with larger cash flow and fewer profitable investment opportunities are more likely to pay their earnings as a dividend[3]. The "life cycle" theory proposes that firms will adjust their dividend policies as their growth opportunities change over time. Firms pay fewer dividends as their investment opportunities rises. Mitton (2004) demonstrates that among firms with more growth opportunities, the positive relation between corporate governance and dividend payouts is weaker. The present study therefore summarizes these predictions as the following second hypothesis:

H2: Growth opportunities will decrease dividend payouts.

H2a: The positive effect of corporate governance on dividends will be attenuated by the growth opportunities of the firm.

Monkhouse (1993) found that, under the tax imputation system in Australia, the ideal dividend policy is to allocate all its franking credit as dividends. This view has also been corroborated by other researchers (Brown and Clarke, 1993; Pattenden and Twite, 2008). This argument indicates that a tax system needs to be included in the analysis of corporate 
dividend payouts. In contrast with many countries where taxes are levied both on corporate level (i.e., corporate tax on profit) and individual level (i.e., income tax), the franked dividend system in Australia refers to a single tax. That is, shareholders obtain tax credits when firms pay tax on their dividend payable profits. Usually, this franked dividend system motivates shareholders to request more dividends than when under the standard double taxation system. Indeed, cash distribution under the franked dividend system is a way to increase shareholder's wealth. Considering that the ultimate goal of corporate governance is to protect minority shareholders' interest, the present study therefore summarizes the third hypothesis:

H3: A franked dividend tax system increases corporate payouts.

H3a: The positive effect of corporate governance on dividends will be intensified by franked dividends.

\section{Model}

This study used the random effect panel Tobit regression because the dividend payout ratio should be non-negative, but less than unity. Tobit estimations can eliminate biases associated with OLS regressions in the presence of censored dependent variables (Kim and Maddala, 1992; Greene, 2003). The baseline estimation model for dividend payout therefore is:

$$
Y_{i t}=\alpha_{0}+\alpha_{1}\left(\text { CGI }_{i t}\right)+\alpha_{2}\left(\text { Firm size }_{i t}\right)+\alpha_{3}\left(\text { Profitability }_{i t}\right)-\alpha_{4}\left(\text { Leverage }_{i t}\right)-\alpha_{5}(\text { Growth }
$$
opportunities $\left._{i t}\right)-\alpha_{6}\left(\right.$ Firm growth $\left._{i t}\right)-\alpha_{7}\left(\right.$ Cash $\left._{i t}\right)-\alpha_{8}\left(\right.$ Free cash flow $\left._{i t}\right)-\alpha_{9}\left(\right.$ Financial distress $\left._{i t}\right)+$ $\alpha_{10}\left(\right.$ Dividend-track $\left._{i t}\right)-\alpha_{11}\left(\right.$ Liquidity-test $\left._{i t}\right)+\sum$ Industry $+\varepsilon_{i t}$

where: $Y_{i . t}$ refers to the firm's (i's at the time $t$ ) cash distribution, calculated by dividends per share divided by net profit after tax before abnormal. CGI refers to the corporate governance index, which is calculated by three different methods for robustness checks. hypothesis 1 implies the sign of the estimated coefficient $\alpha_{1}$ to be positive. Furthermore, 
controlled by the firm size, a larger firm may access the financial market more easily than smaller firms, which can relax cash flows and thus affect the firm's dividend policy. This study is also controlled by the firm's leverage. However, the expected sign of leverage is complex. From the agency perspective, leverage and dividend can be complementary in that they both play a role in monitoring and disciplining managers' self-interest behaviours (Rediker and Seth, 1995) or they can act as substitutes of each other (Crutchley and Hansen, 1989), which result in some monitoring degree. Growth opportunities and firm growth will have negative signs because increased profitable investment, rather than cash dividend at the current time, will increase expected cash flows in the future; which is reflected in the price of shares and thus increases the wealth of shareholders more than cash dividends. The signaling theory suggests that firms want to maintain a sustainable dividend policy; if a firm distributed dividends in one year and then ceased to do so the following year, market investors may interpret the outcome as a signal of the firm's poor performance.

Liquidity is calculated as a proportion of cash to total assets. Free cash flow (FCF) is calculated as net cash after operating and investing cash flow in to total market capital. Given the corporate governance index, which is the main independent variable, the expected signs of liquidity and FCF are complex. The substitution proposition predicts the sign to be negative when the corporate governance is controlled. The agency theory indicates that improved governance will reduce both 'exploitable' cash and FCF. Thus, the residual balance of 'clean' cash and FCF can be substituted for dividends. The “outcomes” model (La Porta et al., 2000) claims a positive sign of liquidity as it takes into account pressures from minority shareholders on the managers to increase the exceeded cash as dividends.

Liquidity-test is a dummy variable equal to one if a firm's total assets minus total liability exceeds the amount of money declared as dividends, and zero otherwise. The estimated sign of the liquidity-test is negative because it constrains dividend according to the balance-sheet 
values of assets and liabilities. Dividend-track is also a dummy variable equal to one if the firm paid a dividend in the previous year, and zero otherwise. Franked dividend is a percentage of dividends with dividend imputation that creates a tax credit to eliminate the double taxation of cash payouts from a company. Financial Distress is a dummy variable equal to one if the firm experiences a two-year consecutive loss, and zero otherwise. Following the signaling theory (DeAngelo et al., 1992; Myers and Majluf, 1984), this study expects financial distress to have a negative effect on the dividend payout ratio as firms try to send a signal to the market that their permanent earnings have declined (DeAngelo et al., 1992).

Australian companies increase their dividend payout in order to distribute their imputation credits and to satisfy the demand of their stockholder clientele (Bellamy, 1994). In order to test the effect of the tax imputation system that dominated Australia, and consistent with the study of Henry (2011), this study uses the percentage of franked dividend as proxy for the tax imputation system. A positive sign of this franked dividend variable is expected.

To investigate the moderation effects by performance, growth opportunities, free cash flow and franked dividend, the baseline model is extended as follows:

$$
\mathrm{Y}_{i t}=\alpha_{0}+\alpha_{1}\left(\mathrm{CGI}_{i t}\right)+\alpha_{2}\left(\text { Firm size }_{i t}\right)+\alpha_{3}\left(\text { Profitability }_{i t}\right)+\alpha_{4}\left(\text { Leverage }_{i t}\right)-\alpha_{5}(\text { Growth }
$$
opportunities $\left._{i t}\right)-\alpha_{6}\left(\right.$ Firm growth $\left._{i t}\right)-\alpha_{7}\left(\right.$ Cash $\left._{i t}\right)-\alpha_{8}\left(\right.$ Free cash flow $\left._{i t}\right)-\alpha_{9}\left(\right.$ Financial distress $\left._{i t}\right)+$ $\alpha_{10}\left(\right.$ Dividend-track $\left._{i t}\right)-\alpha_{11}\left(\right.$ Liquidity-test $\left._{i t}\right)+\sum_{k=12}^{13} \alpha_{k} C G I_{i t} \times M V_{i t, k}+\sum$ Industry $+\varepsilon_{i t}$

where MV refers to growth opportunities and franked dividend. Empirical hypotheses H2a and HЗa respectively imply that signs of the estimated coefficients of these variables are negative and positive respectively.

\section{Data and descriptive statistics}

\subsection{Construction of corporate governance index}


Following the seminal paper by Gompers et al. (2003), the corporate governance index has been frequently used by other researchers (Brown, 2006; Jiraporn et al., 2012; Sawaki, 2009). In particular, Sawaki (2009) proposed governance index in the nexus of dividend payouts based on four different categories: board of directors, audit, and remuneration and nomination committees. These four important elements of governance, as individual elements, have been used by empirical researchers, including Prommin et al. (2014) to test the effect of governance on stock liquidity and Christensen et al. (2010) and to examine the effect of governance on firm performance in Australia. This study adopts the spirit of these four major governance elements. However, the thirteen different corporate governance variables used in this study are promulgated by the ASX Corporate Governance Council (2003) and related literatures in the context of Australia (refer to Table 1).

The Corporate Governance Index (CGI I) covering the thirteen elements in Table 1 is expected to effectively capture a firm's governance structure, practices and related policies. The value of CGI is based on the accumulated score from the confirmation (" 1 ”, not "0") of whether a firm meets the required condition for each of the thirteen governance variables. Therefore, the CGI ranges from a maximum of thirteen to a minimum of zero (refer to Appendix 1 for the details). A score closer to thirteen is means a better governance system.

Table 1: Corporate governance Index I variables

(1)Board function
Board size (measured as the number of directors in each company during
the year), more than the mean of board size in each year.
Independence of the directors on the board (measured as the proportion of
non-executive directors on the board (Monem, 2013), more than 50
percent of directors.
Number of board meetings (measured as the number of board meetings in
each company), more than the mean of board meetings in each year.
Chairman and CEO separation.
Directors' shareholding (measured as the total number of shares held by
directors in each company) more than 5\% of total outstanding shares in
the company.
CEOs' shareholding (measured as the number of shares held by the CEO
in each company) more than 5\% of total outstanding shares in the
company.




\begin{tabular}{|c|c|}
\hline (2)Audit committee & $\begin{array}{l}\text { Existence of an audit committee } \\
\text { The committee meets at least once annually } \\
\text { Engagement of Big Four auditors }\end{array}$ \\
\hline $\begin{array}{l}\text { (3)Remuneration } \\
\text { committee }\end{array}$ & $\begin{array}{l}\text { Existence of a remuneration committee } \\
\text { The committee meets at least once annually }\end{array}$ \\
\hline $\begin{array}{l}\text { (4)Nomination } \\
\text { committee }\end{array}$ & $\begin{array}{l}\text { Existence of a nomination committee } \\
\text { The committee meets at least once annually }\end{array}$ \\
\hline
\end{tabular}

Further, this study calculates the second governance index (CGI II) following corporate governance rating (published in the WHK Horwath/University of Newcastle Corporate Governance Reports), which includes categories such as the board of directors, audit committee, remuneration and nomination committee, external auditor independence and code of conduct. However, the Horwath index has a number of drawbacks for this study. For example, the index only provides a rating for the top 500 firms each year. Most of the top companies in Australia have a strong board structure. Companies included in the Horwath index also included financial and utility firms, which have a different structure of ownership and financial statements; therefore, the Horwath sample is limited in number and out of date for testing of the relation between governance and dividend payouts for current investors and researchers. Also, the index gives the companies a star rating from 1 to 5 and the exact of this weighting is proprietary and not available to the public. The current study develops CGI II based on fourteen governance variables for the Horwath index during the years 2001 to 2013 as shown in Table 2.

Table 2: Corporate governance Index II variables. Based on the Principles in WHK Horwath /University of Newcastle Corporate Governance Reports available variables.
(1)Board of
1.1The most desirable outcome will be for a company to have:
Directors
1.1.1 A board with a majority of independent directors (measured as the proportion of independent directors on the board)
1.1.3 Meeting at least six times annually
1.2 The least desirable outcome will be for a company:
1.2.1 To have a board with no independent director
1.2.2 To have the CEO as chairperson; 
1.2.3 Meets less than six times annually.

(2)Audit 2.1 The most desirable outcome will be for a company to have an audit committee committee:

2.1.4 With at least three members

2.1.5 That does not comprise the full board;

2.1.6 That meets at least four times annually

2.2 The least desirable outcome will be for a company not to have an audit committee

(3)Remuneration 3.1 The most desirable outcome will be for a company to have a remuneration committee committee:

3.1.2 With at least three members

3.1.3That does not comprise the full board;

3.2 The least desirable outcome will be for a company not to have a remuneration committee

(4)Nomination 4.1 The most desirable outcome will be for a company to have a nomination committee committee:

4.1.2 With at least three members

4.1.3That does not comprise the full board;

4.2 The least desirable outcome will be for a company not to have a nomination committee

Note:

This table identifies the criteria used in constructing the governance index. Each question is constructed in a manner that the answer 'yes' adds one point to the governance score. The rating is on a scale of zero to fourteen, with a higher score indicating better governance.

The third governance index (CGI III) follows the Aggarwal et al. (2011). The index provides a firm-level governance measure that is comparable across countries. It focuses on the governance variables most frequently used by researchers which includes categories such as the board structure, audit selection, compensation and ownership structure. The index developed in the present paper is based on five of the available variables that are identified with their code number in the Table 3.

Table 3: Corporate governance Index III variables. Base on the Aggarwal et al. (2011) available variables.

1. All directors attended $75 \%$ of board meetings or had a valid excuse

3. A Board is controlled by more than $50 \%$ independent outside directors (measured as the proportion of independent directors on the board)

4. Board size is at greater than five but less than 16

7. Chairman and CEO positions are separate, or there is a lead director

11. Governance guidelines are publicly disclosed

Note:

This table identifies the criteria used in constructing the governance index. Each question is constructed in a manner that the answer 'yes' adds one point to the governance score. The rating is on a scale of zero to five, with a higher score indicating better governance. 


\subsection{Sample construction and data description}

The initial sample consists of all the companies listed in the Australian Stock Exchange (ASX) from 2001 to 2013 (Table 4). Excluding the financial and utility sectors the final sample consists of 11,174 firm-year observations. Data for dividend payouts and control variables are from the Morningstar database and from companies' annual reports. Data relating to corporate governance was hand-collected from the Australian Company Announcements database SIRCA. Variables were winsorized at the top and bottom 5\% to remove outliers.

Table 4: The type of variables and respective data sources to be used in this study

\begin{tabular}{ll}
\hline Type of variables & \\
\hline Corporate governance variables & SIRCA database \\
& Annual reports available in Connect 4 database \\
\cline { 1 - 2 } Dividend policy variables & Morningstar database \\
& Annual reports \\
& Morningstar database \\
\hline Control variables & SIRCA database \\
\hline
\end{tabular}

Figure 1 shows that the amount of dividend payments increased from just under AU $\$ 23,000$ million in 2001 to about AU\$40,000 million in 2013. Over that period, the portion of dividend payout ratio in Figure 2 also increased from 20\% to about 23\%. However, as shown in Figure 3, the portion of firms that paid dividends increased from 33.21\% in 2001 to around $35.68 \%$ in 2007 , but dropped dramatically to about $32.72 \%$ in 2009 and increased to its highest (38.17\%) in 2013 (Figure 3). This substantial drop indicates the importance of the Global Financial Crisis, which will be examined below. 
Figure 1: Dividend Payment by Australian Firms during 2001-2013

(\$A million)

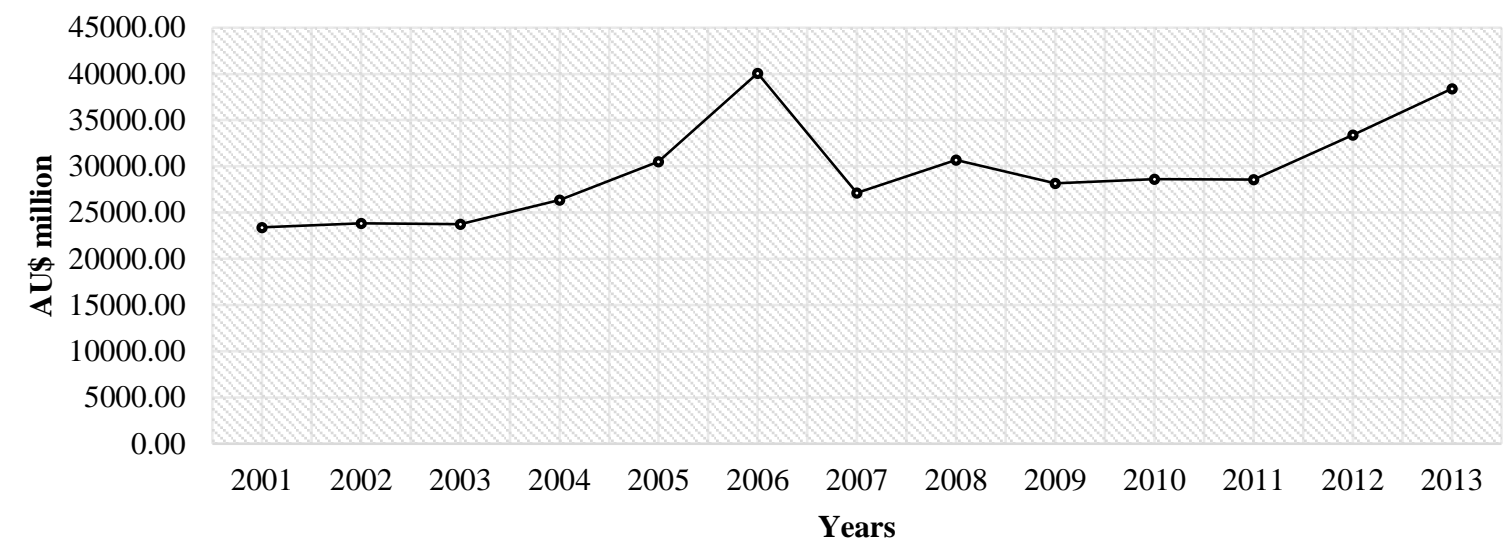

Figure 2: Portion of Dividend to Net profit during 2001-2013

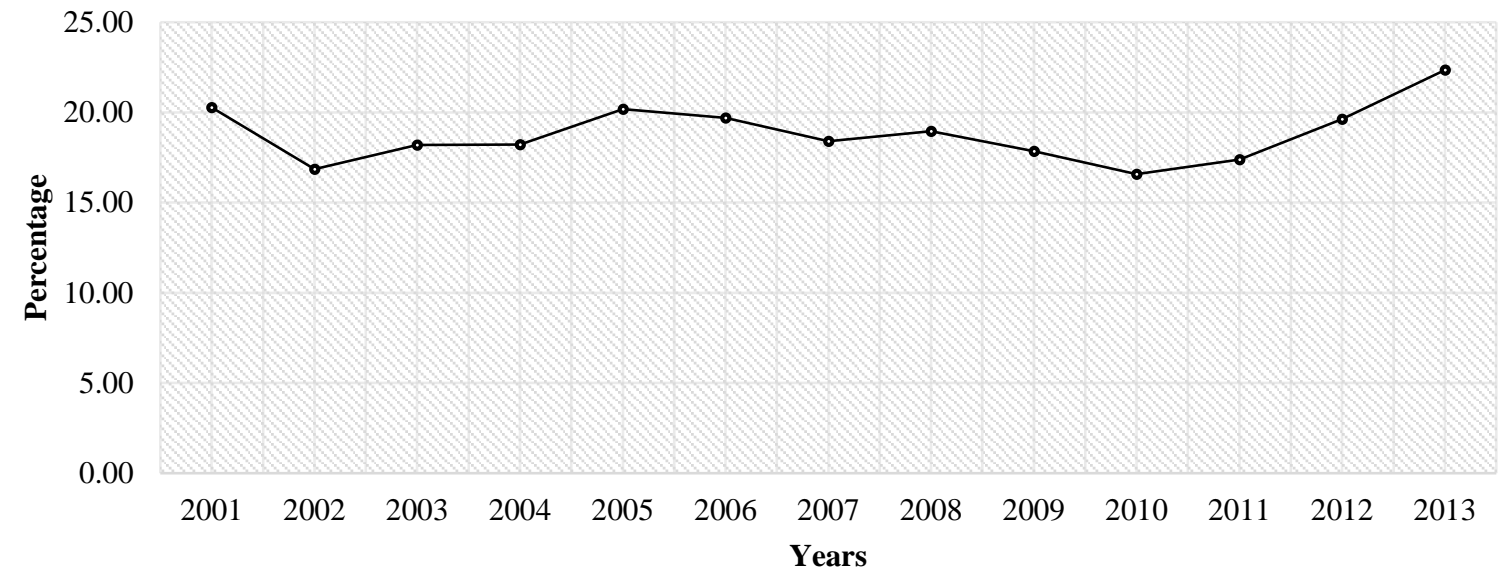

Figure 3: Portion of Dividend Paid Companies during 2001-2013

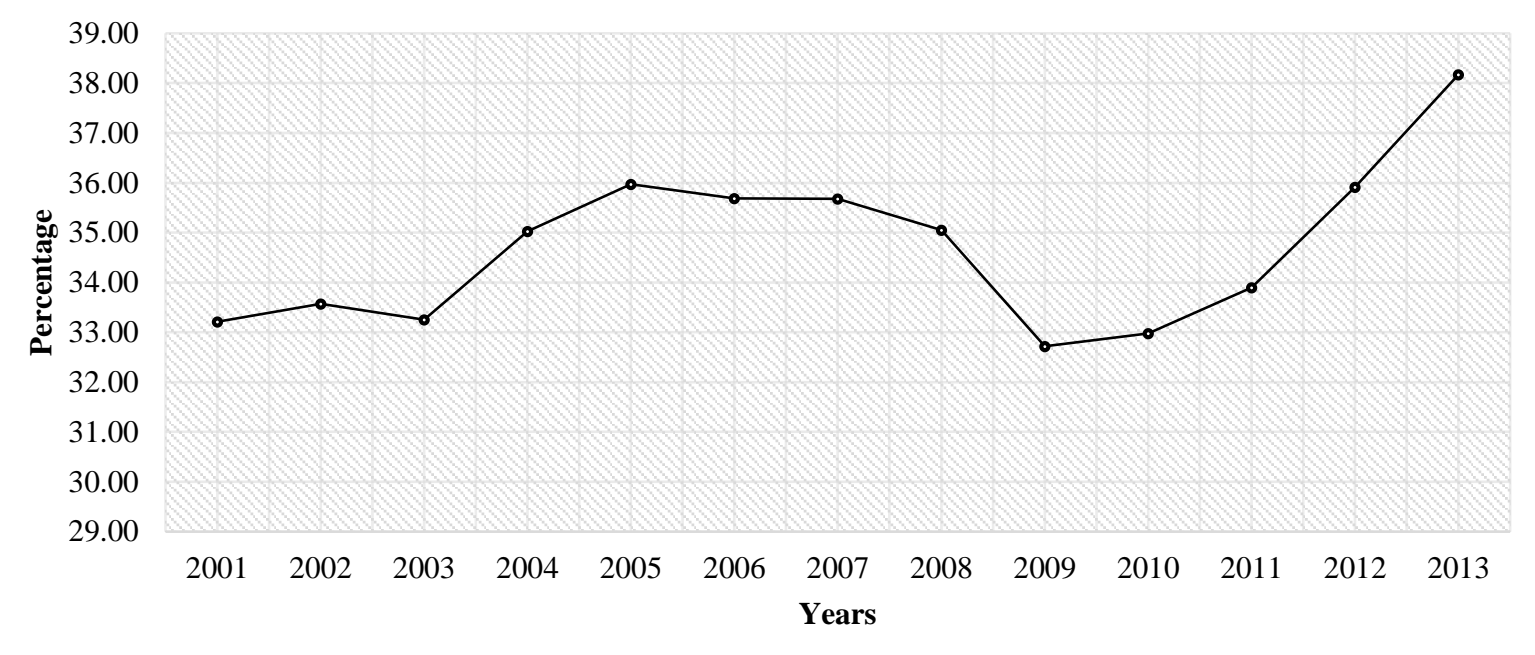


Figure 4 shows the trends of the average level of CGI I, II and III. The level of corporate governance of all three indices increased over the period. CGI I, which is the main index in this study, increased from about $50 \%$ in 2001 to a peak of $73 \%$ in 2008 . This can be due to the effect of GFC because the companies during the period found it more necessary to improve their corporate governance mechanism for better monitoring of the firms. The level of corporate governance shows a significant improvement from 50\% in 2001 to 60\% in 2013. This shows the necessity of corporate governance improvement in the context of Australian firms.

\section{Figure 4: Trend of Average Corporate Governance Indices 2001-2013.}

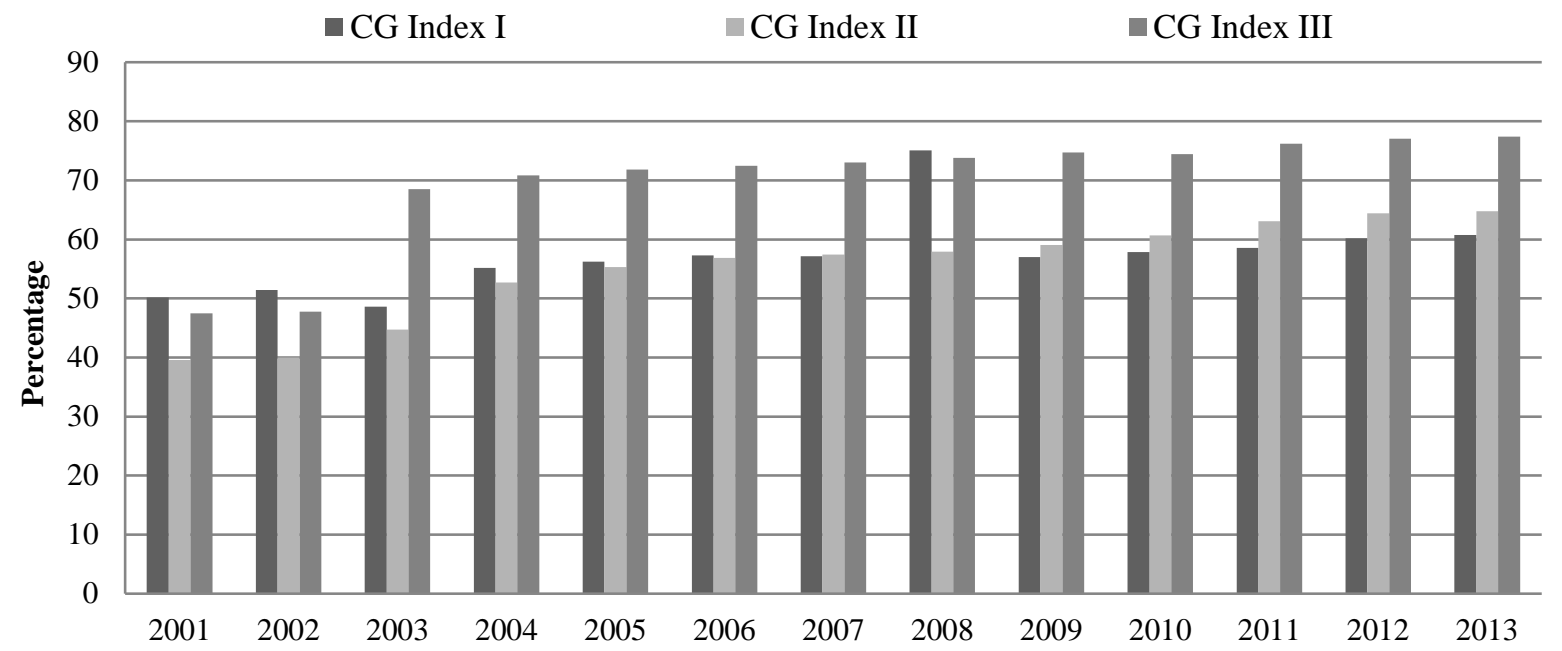

CG Index I is calculated as the summation of the thirteen categories of corporate governance dummy, as described in Table 1, divided by thirteen. As such, the closer to 1 the better the governance system and vice versa. CG Index II is calculated by the same method as for CG Index I but based on the fourteen categories of corporate governance dummies as described in Table 2. CG Index III is calculated based on five dummy variables as described in Table 3.

The trends of each elements of CGI I, II, III are presented in Figure 5. It is apparent that audit, remuneration and nomination committees have become more widely adopted by firms over the period. 


\section{Figure 5: Trend of Corpoate Governance Elements 2001-2013}

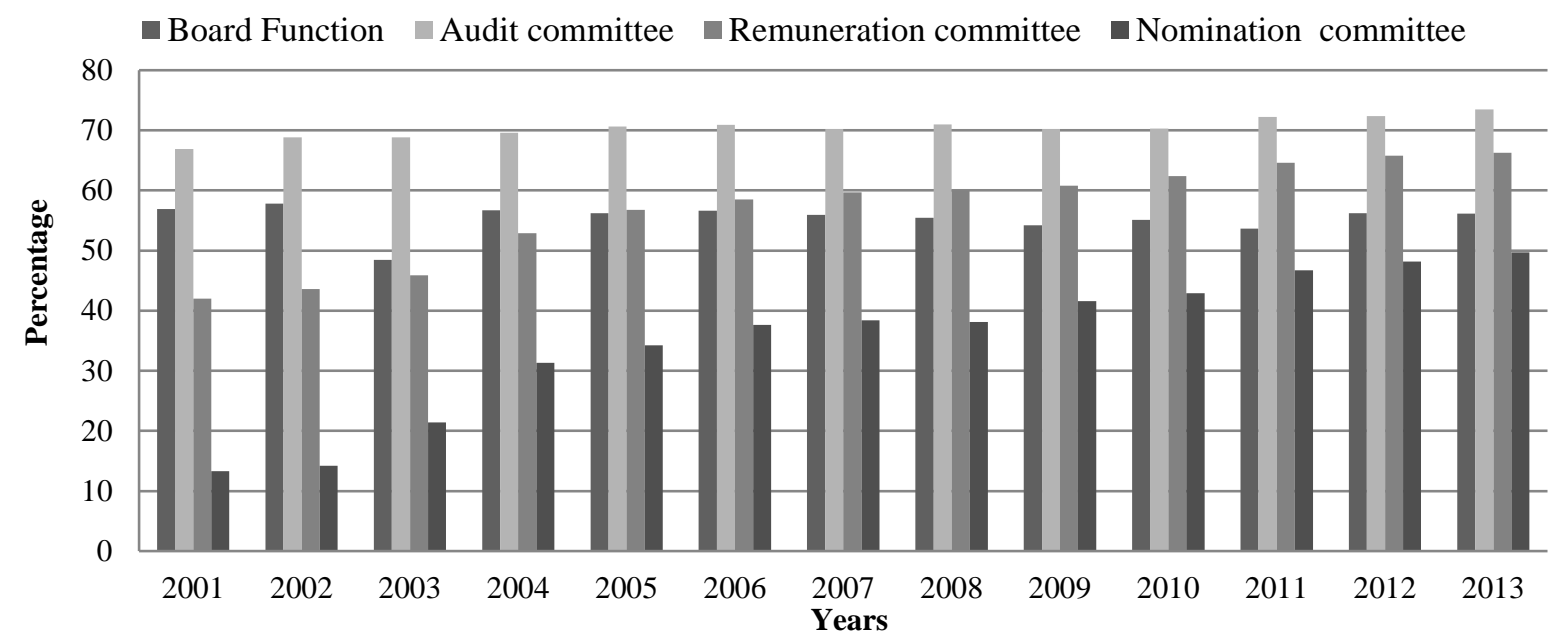

The Board Function index (category) is calculated as the summation of the 6 dummy variables as described in Table 1 . The closer to 6 the better BOD functions to indicates improved governance. The audit committee index (category) is calculated by summation of the 3 variables as described in Table 1 . The closer to 3 the better governance. The nomination and remuneration committee index (category) is the summation of the 2 variables as described in Table 1. The closer to 2 the better governance.

The bar chart in Figure 6 shows that industries with a high CGI index include consumer staples (67\%) and telecommunication services (66\%), whereas the industries with low CGI index are the materials (47\%) and energy sectors (48\%). The line graph shows the portion of dividend paying firms in each industry. The result shows that, on average, companies with stronger CG have a higher tendency to pay dividends. The lower portion of dividend-paying firms in the energy sector can also support the hypothesis 2a, where the positive relation between CG is attenuated by growth (explained in Table 5). 


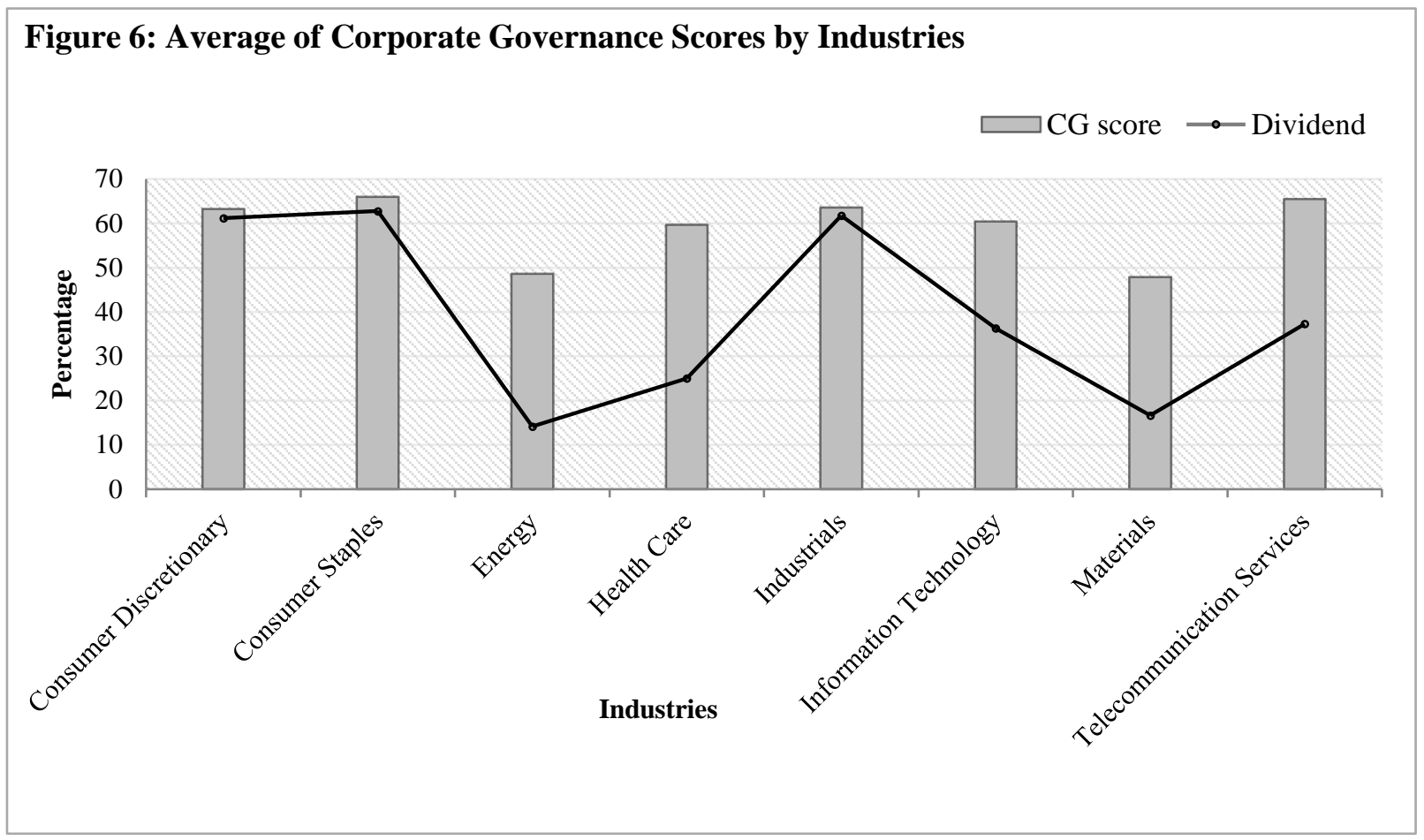

Table 5 shows the descriptive statistics for the variables. Panel A reports the descriptive statistics and panel B reports the Pearson cross-correlation coefficients and the level of significance between the variables.

Table 5: Descriptive Statistics of Variables

Panel A: Summary statistics

\begin{tabular}{lcccccc}
\hline & Obs & Mean & Std. Dev. & Median & Min & Max \\
\hline DP & 11174 & 0.187 & 0.301 & 0 & 0 & 0.933 \\
Governance variables & & & & & & \\
CG Index I & 11393 & 0.558 & 0.222 & 0.615 & 0 & 1 \\
CG Index II & 11393 & 0.548 & 0.285 & 0.571 & 0 & 1 \\
CG Index III & 11393 & 0.695 & 0.192 & 0.6 & 0 & 1 \\
Board function & 11393 & 0.554 & 0.238 & 0.5 & 0 & 1 \\
Audit committee & 11393 & 0.703 & 0.347 & 0.667 & 0 & 1 \\
Remuneration & 11393 & 0.566 & 0.470 & 1 & 0 & 1 \\
committee & & & & & & \\
Nomination committee & 11393 & 0.348 & 0.454 & 0 & 0 & 1 \\
Firm characteristics & & & & & & \\
Firm Size & 11110 & 17.943 & 2.022 & 17.802 & 14.728 & 21.849 \\
Profitability & 11213 & -0.119 & 0.322 & 0 & -1.096 & 0.189 \\
Leverage & 11239 & 0.299 & 0.418 & 0.077 & 0 & 1.461 \\
Growth opportunities & 11222 & 2.429 & 2.347 & 1.62 & 0 & 9.19 \\
Firm Growth & 10986 & 0.227 & 0.619 & 0.055 & -0.529 & 2.131 \\
Liquidity & 11231 & 0.214 & 0.235 & 0.115 & 0.004 & 0.811 \\
& & & & & &
\end{tabular}




\begin{tabular}{lcccccc} 
Free cash flow & 11110 & 0.102 & 0.236 & -0.059 & -0.702 & 0.293 \\
Financial Distress & 11192 & 0.502 & 0.500 & 1 & 0 & 1 \\
Dividend-track & 10856 & 0.339 & 0.473 & 0 & 0 & 1 \\
Liquidity-test & 11174 & 0.958 & 0.199 & 1 & 0 & 1 \\
Franked dividend & 4036 & 0.787 & 0.384 & 1 & 0 & 1 \\
\hline
\end{tabular}

Notes:

Dividend payout ratio (DP) refers to the percentage of dividends out of net profits. CG Index I is calculated as the summation of the thirteen categories of corporate governance dummy, as described in Table 1, divided by thirteen. As such, the closer to 1 the better the governance system and vice versa. CG Index II is calculated by the same method as for CG Index I but based on the fourteen categories of corporate governance dummies as described in Table 2. CG Index III is calculated based on a five dummy variables as described in Table 3. Firm size is calculated as logarithm of the firm's market capitalization. Profitability is calculated as net income over total assets. Leverage is measured as short-term debt plus long term debt divided by total shareholders' equity. Growth opportunities is measured as the market value of equity divided by book value of equity. Firm Growth refers to the 1-year growth rate of total assets. Liquidity is calculated as cash to total assets. Free Cash Flow is the operating cash flow less net capital investments during the year scaled by total assets. Financial Distress is a dummy variable and is equal to one if the firm makes a two-year consecutive loss, and zero otherwise. Dividend-track is also a dummy variable and is equal to one if the firm paid dividend in the previous year, and zero otherwise. Liquidity-test is also a dummy variable and is equal to one if a firm's total assets minus total liability exceeded the amount of money declared as dividends, and zero otherwise. Franked dividend is a percentage of dividends with dividend imputation that creates a tax credit to eliminate the double taxation of cash payouts from a company. 


\section{Panel B: Pearson cross-correlation matrix}

\begin{tabular}{|c|c|c|c|c|c|c|c|c|c|c|c|c|}
\hline Variables & DP & $\begin{array}{c}\text { CG } \\
\text { Index I }\end{array}$ & Firm Size & $\begin{array}{l}\text { Profit- } \\
\text { ability }\end{array}$ & Leverage & $\begin{array}{c}\text { Growth } \\
\text { opportunities }\end{array}$ & $\begin{array}{c}\text { Firm } \\
\text { Growth }\end{array}$ & Cash & $\begin{array}{c}\text { Free cash } \\
\text { flow }\end{array}$ & $\begin{array}{c}\text { Financial } \\
\text { Distress }\end{array}$ & $\begin{array}{c}\text { Dividend } \\
\text {-track }\end{array}$ & $\begin{array}{c}\text { Liquidity } \\
\text {-test }\end{array}$ \\
\hline CG Index I & $0.379 * * *$ & & & & & & & & & & & \\
\hline Firm Size & $0.481^{* * *}$ & $0.534 * * *$ & & & & & & & & & & \\
\hline Profitability & $0.403^{* * *}$ & $0.329 * * *$ & $0.465 * * *$ & & & & & & & & & \\
\hline Leverage & $0.242 * * *$ & $0.251^{* * *}$ & $0.214^{* * *}$ & $0.212 * * *$ & & & & & & & & \\
\hline Growth opportunities & 0.009 & $-0.023 * *$ & $0.203^{* * *}$ & $-0.173^{* * *}$ & $0.051 * * *$ & & & & & & & \\
\hline Firm Growth & $-0.075 * * *$ & $-0.038 * * *$ & $0.153 * * *$ & $0.192 * * *$ & -0.014 & $0.133 * * *$ & & & & & & \\
\hline Liquidity & $-0.277 * * *$ & $-0.240 * * *$ & $-0.227 * * *$ & $-0.351 * * *$ & $-0.391 * * *$ & $0.277 * * *$ & $0.101^{* * *}$ & & & & & \\
\hline Free cash flow & $0.313^{* * *}$ & $0.203^{* * *}$ & $0.337 * * *$ & $0.415^{* * *}$ & 0.011 & $0.090 * * *$ & $-0.049 * * *$ & $-0.042^{* * *}$ & & & & \\
\hline Financial Distress & $-0.443^{* * *}$ & $-0.296 * * *$ & $-0.3^{* * *}$ & $-0.442 * * *$ & $-0.155^{* * *}$ & $0.094 * * *$ & $0.151 * * *$ & $0.167 * * *$ & $-0.537 * * *$ & & & \\
\hline Dividend-track & $0.743 * * *$ & $0.432 * * *$ & $0.541^{* * *}$ & $0.439 * * *$ & $0.283^{* * *}$ & $-0.032 * * *$ & $-0.080 * * *$ & $-0.327 * * *$ & $0.338 * * *$ & $-0.484 * * *$ & & \\
\hline Liquidity-test & $0.093 * * *$ & $0.126^{* * *}$ & $0.189 * * *$ & $0.306^{* * *}$ & $0.129 * * *$ & $0.173^{* * *}$ & $0.137 * * *$ & $-0.023 * *$ & $0.114^{* * *}$ & $-0.074 * * *$ & $0.122^{* * *}$ & \\
\hline Franked dividend & $0.116 * * *$ & $0.078 * * *$ & $-0.147 * * *$ & $0.065^{* * *}$ & -0.016 & $0.038 * *$ & $0.036 * *$ & $-0.049 * * *$ & 0.007 & -0.005 & $0.126 * * *$ & $0.039 * *$ \\
\hline
\end{tabular}


The results show that the average dividend payout (DP) over the period is $18.7 \%$. Over the sample period of 2001 to 2013, the average CGI I (CGI II and CGI III) is 0.558 (0.548 and 0.695 respectively). The average leverage was $29.9 \%$ and liquidity ratio (cash ratio) was $21.4 \%$, whereas the profitability ratio that is return on assets was $-11.9 \%$.

The Pearson pair-wise correlation matrix in panel B shows that CGI I, II, and III are positively and statistically significantly correlated with dividend payouts, which is consistent with the prediction of hypothesis 1 .The dividend payout ratio is positively correlated with firm size, profitability, leverage, free cash flow, dividend of the previous year, dividend test, and franked dividend, and inversely related to firm growth, liquidity (cash ratio), and firm financial distress.

\section{Regression results}

Table 6 shows that the coefficient of CGI I is positive and significant irrespective of model specifications, which is consistent with hypothesis 1 . In addition to the baseline estimation for the effect of governance on payout on Model 1, this study includes growth opportunities variable and other control variables on Model 2 with a view to examining the hypothesis 2. Results in column 2 show a negative coefficient of growth opportunities as expected. Meanwhile, the positive effect of governance remains positive and significant although the magnitude of estimated coefficient dropped almost by $80 \%$.

The rest of models in Table 6 examine the effect of the Australian tax system, captured by the franked-dividend system, on dividends. As the hypothesis 3 indicates, the estimated sign of the franked dividend variable was positive throughout the Models 3 to 6. Because of the limited number of observations for the franked dividend variable, efficiency of the estimation dropped substantially. Despite this decrease in efficiency of estimation, all the main independent variables (i.e., CGI, Growth Opportunities and Franked Dividend) report the 
significant coefficient for the expected signs. For further robustness checks, this study estimated using CGI II and CGI III. Results in Table 7 confirm that the main finding is robust against different constructions of governance indexes.

Table 6: Tobit Estimation of the Effect of Corporate Governance Index I on Cash Dividend

\begin{tabular}{|c|c|c|c|c|c|}
\hline & Model 1 & Model 2 & Model 3 & Model 4 & Model 5 \\
\hline CG Index I & $\begin{array}{c}0.566^{* * *} \\
(13.93)\end{array}$ & $\begin{array}{c}0.100 * * * \\
(2.64)\end{array}$ & $\begin{array}{c}0.099 * * * \\
(2.67)\end{array}$ & $\begin{array}{c}0.110^{* * *} \\
(2.79)\end{array}$ & $\begin{array}{c}0.094^{* *} \\
(2.53)\end{array}$ \\
\hline Firm Size & & $\begin{array}{c}0.069 * * * \\
(13.68)\end{array}$ & $\begin{array}{c}0.012 * * * \\
(2.57)\end{array}$ & $\begin{array}{c}0.03^{* * * *} \\
(6.08)\end{array}$ & $\begin{array}{c}0.014 * * * \\
(3.12)\end{array}$ \\
\hline Profitability & & $\begin{array}{c}2.063 * * * \\
(22.48)\end{array}$ & $\begin{array}{c}0.638 * * * \\
(6.60)\end{array}$ & $\begin{array}{c}0.585^{* * * *} \\
(5.90)\end{array}$ & $\begin{array}{c}0.659 * * * \\
(6.77)\end{array}$ \\
\hline Leverage & & $\begin{array}{c}0.060 * * * \\
(3.85)\end{array}$ & $\begin{array}{c}0.040 * * * \\
(2.61)\end{array}$ & $\begin{array}{c}0.038^{* *} \\
(2.39)\end{array}$ & $\begin{array}{c}0.046^{* * *} \\
(3.09)\end{array}$ \\
\hline $\begin{array}{l}\text { Growth } \\
\text { opportunities }\end{array}$ & & $\begin{array}{c}-0.026^{* * *} \\
(-7.28)\end{array}$ & $\begin{array}{c}-0.006^{*} \\
(-1.87)\end{array}$ & $\begin{array}{c}-0.008^{* *} \\
(-2.40)\end{array}$ & $\begin{array}{c}-0.008^{* * * *} \\
(-2.68)\end{array}$ \\
\hline Firm Growth & & $\begin{array}{c}-0.057 * * * \\
(-4.92)\end{array}$ & $\begin{array}{c}-0.076 * * * \\
(-6.57)\end{array}$ & $\begin{array}{c}-0.08^{* * * *} \\
(-7.23)\end{array}$ & $\begin{array}{c}-0.091 * * * \\
(-7.44)\end{array}$ \\
\hline Liquidity & & $\begin{array}{c}-0.139 * * * \\
(-3.23)\end{array}$ & $\begin{array}{c}-0.146 * * * \\
(-3.33)\end{array}$ & $\begin{array}{c}-0.22 * * * \\
(-4.78)\end{array}$ & \\
\hline Free cash flow & & & & & $\begin{array}{c}-0.109 * * * \\
(-3.38)\end{array}$ \\
\hline $\begin{array}{l}\text { Financial- } \\
\text { Distress }\end{array}$ & & $\begin{array}{c}-0.094^{* * *} \\
(-7.13)\end{array}$ & $\begin{array}{c}-0.032 * * \\
(-2.52)\end{array}$ & $\begin{array}{c}-0.026^{* *} \\
(-2.00)\end{array}$ & $\begin{array}{c}-0.042^{* * * *} \\
(-3.13)\end{array}$ \\
\hline Dividend-track & & $\begin{array}{c}0.428 * * * \\
(27.67)\end{array}$ & $\begin{array}{c}0.231^{* * * *} \\
(16.75)\end{array}$ & & $\begin{array}{c}0.234 * * * \\
(17.00)\end{array}$ \\
\hline Liquidity-test & & $\begin{array}{c}-0.088^{*} \\
(-1.89)\end{array}$ & $\begin{array}{c}-0.274^{* * * *} \\
(-4.89)\end{array}$ & $\begin{array}{c}-0.29 * * * \\
(-5.09)\end{array}$ & $\begin{array}{c}-0.254 * * * \\
(-4.54)\end{array}$ \\
\hline Franked-dividend & & & $\begin{array}{c}0.033 * * * \\
(2.14)\end{array}$ & $\begin{array}{c}0.061^{* * *} \\
(3.69)\end{array}$ & $\begin{array}{c}0.035^{* *} \\
(2.28)\end{array}$ \\
\hline Intercept & $\begin{array}{c}-0.634^{* * *} \\
(-5.02)\end{array}$ & $\begin{array}{c}-1.46 * * * \\
(-13.75)\end{array}$ & $\begin{array}{l}0.153 \\
(1.44)\end{array}$ & $\begin{array}{l}-0.069 \\
(-0.60)\end{array}$ & $\begin{array}{l}0.080 \\
(0.76)\end{array}$ \\
\hline Industry Dummy & Yes & Yes & Yes & Yes & Yes \\
\hline Firm-years & 11174 & 10704 & 3919 & 3974 & 3919 \\
\hline Number of firms & 1125 & 1207 & 646 & 650 & 646 \\
\hline Log likelihood & -3897.76 & -2364.74 & -843.38 & -1044.89 & -843.25 \\
\hline Probability & 0.000 & 0.000 & 0.000 & 0.000 & 0.000 \\
\hline
\end{tabular}

\section{Notes:}

Dividend payout ratio (DP), the dependent variable, refers to the percentage of dividends out of net profits. CG Index I is calculated as the summation of the thirteen categories of corporate governance dummy, as described in Table 1, divided by thirteen. As such, the closer to 1 the better the governance system and vice versa. Firm size is calculated as logarithm of the firm's market capitalization. Profitability is calculated as net income over total assets. Leverage is measured as short-term debt plus long term debt divided by total shareholders' equity. Growth opportunities is measured as the market value of equity divided by book value of equity. Firm Growth refers to the 1-year growth rate of total assets. Liquidity is calculated as cash to total assets. Free Cash Flow is the operating cash flow less net capital investments during the year scaled by total assets. Financial Distress is a dummy variable and is equal to one if the firm makes a two-year consecutive loss, and zero otherwise. Dividend-track is also a dummy variable and is equal to one if the firm paid dividend in the previous year, and zero otherwise. Liquidity-test is also a dummy variable and is equal to one if a firm's total assets minus total liability exceeded the amount of money declared as dividends, and zero otherwise. Franked dividend is a percentage of dividends with dividend imputation that creates a tax credit to eliminate the double taxation of cash payouts from a company. $*, * *, * * *$ denote significance at the $10 \%, 5 \%$ and $1 \%$ levels, respectively. 
Table 7: Tobit Estimation of the Effect of Corporate Governance Index II and III on Cash Dividend

\begin{tabular}{|c|c|c|c|c|}
\hline & Model 1 & Model 2 & Model 3 & Model 4 \\
\hline CG Index II & $\begin{array}{c}0.44^{* * *} \\
(14.38)\end{array}$ & $\begin{array}{c}0.054^{* *} \\
(1.97)\end{array}$ & & \\
\hline CG Index III & & & $\begin{array}{c}0.309 * * * \\
(9.31)\end{array}$ & $\begin{array}{l}0.053^{*} \\
(1.85)\end{array}$ \\
\hline Firm Size & & $\begin{array}{c}0.011^{* *} \\
(2.41)\end{array}$ & & $\begin{array}{c}0.013^{* * *} \\
(2.76)\end{array}$ \\
\hline Profitability & & $\begin{array}{c}0.633^{* * * *} \\
(6.56)\end{array}$ & & $\begin{array}{c}0.634 * * * \\
(6.58)\end{array}$ \\
\hline Leverage & & $\begin{array}{c}0.040^{* * *} \\
(2.65)\end{array}$ & & $\begin{array}{c}0.041^{* * * *} \\
(2.71)\end{array}$ \\
\hline $\begin{array}{l}\text { Growth } \\
\text { opportunities }\end{array}$ & & $\begin{array}{c}-0.006^{*} \\
(-1.84)\end{array}$ & & $\begin{array}{c}-0.006^{*} \\
(-1.89)\end{array}$ \\
\hline Firm Growth & & $\begin{array}{c}-0.075^{* * * *} \\
(-6.46)\end{array}$ & & $\begin{array}{c}-0.076^{* * * *} \\
(-6.56)\end{array}$ \\
\hline Liquidity & & $\begin{array}{c}-0.146 * * * \\
(-3.34)\end{array}$ & & $\begin{array}{c}-0.146^{* * * *} \\
(-3.33)\end{array}$ \\
\hline Financial-Distress & & $\begin{array}{c}-0.032 * * \\
(-2.48)\end{array}$ & & $\begin{array}{c}-0.032 * * \\
(-2.51)\end{array}$ \\
\hline Dividend-track & & $\begin{array}{c}0.231 * * * \\
(16.76)\end{array}$ & & $\begin{array}{c}0.231 * * * \\
(16.76)\end{array}$ \\
\hline Liquidity-test & & $\begin{array}{c}-0.274^{*} \\
(-4.88)\end{array}$ & & $\begin{array}{l}-0.271^{*} \\
(-4.83)\end{array}$ \\
\hline Franked dividend & & $\begin{array}{c}0.035^{* *} \\
(2.28)\end{array}$ & & $\begin{array}{c}0.037 * * \\
(2.37)\end{array}$ \\
\hline Intercept & $\begin{array}{c}-0.546^{* * *} \\
(-4.40)\end{array}$ & $\begin{array}{l}0.187^{*} \\
(1.71)\end{array}$ & $\begin{array}{l}-0.495 \\
(-3.72)\end{array}$ & $\begin{array}{c}0.160^{* * *} \\
(1.49)\end{array}$ \\
\hline Industry Dummy & Yes & Yes & Yes & Yes \\
\hline Firm-years & 11174 & 3919 & 11174 & 3919 \\
\hline Number of firms & 1225 & 646 & 1225 & 646 \\
\hline Log likelihood & -3879.46 & -845.00 & -3940.23 & -845.23 \\
\hline Probability & 0.000 & 0.000 & 0.000 & 0.000 \\
\hline
\end{tabular}

Notes:

Dividend payout ratio (DP), the dependent variable, refers to the percentage of dividends out of net profits. CG Index II is calculated by the same method as for CG Index I but based on the fourteen categories of corporate governance dummies as described in Table 2. CG Index III is calculated based on a five dummy variables as described in Table 3. Firm size is calculated as logarithm of the firm's market capitalization. Profitability is calculated as net income over total assets. Leverage is measured as short-term debt plus long term debt divided by total shareholders' equity. Growth opportunities measured as the market value of equity divided by book value of equity. Firm Growth refers to the 1-year growth rate of total assets. liquidity is calculated as cash to total assets. Free Cash Flow is the operating cash flow less net capital investments during the year scaled by total assets. Financial Distress is a dummy variable and is equals to one if the firm makes two year consecutive loss, and zero otherwise. Dividend-track is also a dummy variable and is equal to one if the firm paid dividend in the previous year, and zero otherwise. Liquidity-test is also a dummy variable and is equal to one if a firm's total assets minus total liability exceeded the amount of money declared as dividends, and zero otherwise. Franked dividend is a percentage of dividends with dividend imputation that creates a tax credit to eliminate the double taxation of cash payouts from a company. $*, * *, * * *$ denote significance at the $10 \%, 5 \%$ and $1 \%$ levels, respectively. 
Estimated coefficients of the control are also consistent with expectations. The positive sign of firm size is consistent with the studies of Setia-Atmaja et al. (2009) and Coulton and Ruddock (2011). The estimated coefficients of profitability and leverage ratio are positive, as expected. The results also show a significant inverse relation of growth opportunities with dividend payouts, supporting the life cycle hypothesis, which is similar to the findings of Rozeff (1982), Farinha (2003) and Coulton and Ruddock (2011).

The negative relation between liquidity (free cash flow) and dividend payouts supports the substitute model, which predicts improvement in corporate governance distributing 'free' cash and makes remaining liquidity and FCF to be substitutable for dividend. The positive association between dividend payment of the previous year (dividend-track) and dividend payout of the current year supports the signaling hypothesis. The results show the liquidity test dummy variable is negative.

Table 8: Tobit Estimation of the Effect of Corporate Governance Index I on Cash Dividend: Moderation effect by Growth Opportunities and franked dividend

\begin{tabular}{lcc}
\hline & Model 1 & Model 2 \\
\hline CG Index I & $0.110^{* * *}$ & -0.034 \\
& $(2.89)$ & $(-0.51)$ \\
CG Index I * Growth opportunities & $-0.053^{* *}$ & \\
& $(-2.30)$ & $0.182^{* *}$ \\
CG Index I * Franked dividend & & $(2.37)$ \\
& & $0.011^{* *}$ \\
Firm Size & $0.069^{* * *}$ & $(2.52)$ \\
& $(13.72)$ & $0.638^{* * *}$ \\
Profitability & $2.082^{* * *}$ & $(6.59)$ \\
& $(22.53)$ & $0.040^{* * *}$ \\
Leverage & $0.060^{* * *}$ & $(2.61)$ \\
& $(3.83)$ & $-0.006^{*}$ \\
Growth opportunities & $-0.020^{* * *}$ & $(-1.80)$ \\
& $(-4.71)$ & $-0.077^{* * *}$ \\
Firm Growth & -0.057 & $(-6.67)$ \\
& $(-4.99)$ & $-0.147^{* * *}$ \\
Liquidity & $-0.140^{* * *}$ & $(-3.37)$ \\
Financial-Distress & $(-3.25)$ & $-0.033^{* *}$ \\
& $-0.094^{* * *}$ & $(-2.58)$ \\
Dividend-track & $(-7.11)$ & $0.232^{* * *}$ \\
& 0.428 & $(16.82)$
\end{tabular}




\begin{tabular}{lcc} 
Liquidity-test & $-0.084^{*}$ & -0.087 \\
& $(-1.81)$ & $(-1.64)$ \\
Franked dividend & -0.087 \\
& & $(-1.64)$ \\
Intercept & $-1.475^{* * *}$ & $0.248^{* *}$ \\
& $(-13.85)$ & $(2.17)$ \\
Industry Dummy & Yes & yes \\
Firm-years & 10704 & 3919 \\
Number of firms & 1207 & 646 \\
Log likelihood & -2362.09 & -840.569 \\
Probability & 0.000 & 0.000 \\
\hline Notes: & \\
CG Index I $*$ Growth Opportunities and CG Index I * Franked dividend refers interaction variables. The control variables \\
are defined as same as in Table 7. \\
*,**,*** denote significance at the $10 \%, 5 \%$ and 1\% levels, respectively. \\
\hline
\end{tabular}

To investigate hypotheses 2a and 3a, this study included interaction variables as reported in Table 8. The results in Table 8 show the positive effect of corporate governance moderated by growth opportunities (Model 1) and franked dividend (Model 2). As suggested by La Porta et al. (2000) and Mitton (2004), the negative sign of the interaction between governance and growth opportunities, CGI I* Growth opportunities, implies an attenuation effect by growth opportunities. Governance variable of CGI I remains significant with the expected sign when including the interaction variable of CGI I* Growth opportunities. This means, for example, the magnitude of the (net) effect of CGI I on dividend is positive (with the magnitude of 0.1 ) for firms with zero growth opportunities. This magnitude of governance is almost the same as the results on the unrestricted models in Table 6 .

The results in Model 2 in Table 8 show that the positive relation between corporate governance and dividend payouts will be intensified by franked dividends, as predicted by hypothesis 3a. Interestingly, the governance variable CGI I is no longer statistically significant when we control for the interaction variable with franked dividend. These findings suggest that the net effect of corporate governance on dividend is not significant for firms without a franked dividend system.

\section{Further analyses and robustness checks}




\subsection{Analysis of corporate governance categories}

The main index developed for corporate governance in this study is based on thirteen governance variables which are grouped into four categories: the board of directors, audit, remuneration and nomination committees. The use of CGI implicitly assumes that each of these individual governance categories is equally weighted. To examine the possibility of the different plays of each of these categories in motivating dividend payouts, this study estimates the same models by replacing the CGI with each of these governance categories (Table 9). 
Table 9:Tobit Estimation of the Effect of Governance Categories on Cash Dividend

\begin{tabular}{|c|c|c|c|c|c|c|c|c|c|c|}
\hline & Model 1 & Model 2 & Model 3 & Model 4 & Model 5 & Model 6 & Model 7 & Model 8 & Model 9 & Model 10 \\
\hline Board Function & $\begin{array}{c}0.117^{* * * *} \\
(3.42)\end{array}$ & $\begin{array}{c}0.155^{* * * *} \\
(4.55)\end{array}$ & $\begin{array}{c}0.214^{* * * *} \\
(6.42)\end{array}$ & $\begin{array}{c}0.156 * * * \\
(4.60)\end{array}$ & & & & & & \\
\hline Audit committee & $\begin{array}{c}0.229 * * * \\
(6.14)\end{array}$ & $\begin{array}{c}0.05 \\
(1.58)\end{array}$ & & & $\begin{array}{c}0.362 * * * \\
(10.39)\end{array}$ & $\begin{array}{l}0.054^{*} \\
(1.82)\end{array}$ & & & & \\
\hline Remuneration committee & $\begin{array}{c}0.126 * * * \\
(6.36)\end{array}$ & $\begin{array}{l}0.011 \\
(0.69)\end{array}$ & & & & & $\begin{array}{c}0.198 * * * \\
(11.00)\end{array}$ & $\begin{array}{l}0.016 \\
(1.07)\end{array}$ & & \\
\hline Nomination committee & $\begin{array}{l}0.052 * * * \\
(3.14)\end{array}$ & $\begin{array}{c}-0.032 * * \\
(-2.31)\end{array}$ & & & & & & & $\begin{array}{l}0.126^{* * * *} \\
\quad(8.20)\end{array}$ & $\begin{array}{c}-0.0206 \\
(-1.54)\end{array}$ \\
\hline Intercept & $\begin{array}{c}-0.629 * * * \\
(-5.04)\end{array}$ & $\begin{array}{l}-1.58 * * * \\
(-14.39)\end{array}$ & $\begin{array}{c}-0.398 * * * \\
(-3.02)\end{array}$ & $\begin{array}{l}-1.56 * * * \\
(-14.52)\end{array}$ & $\begin{array}{c}-0.555^{* * *} \\
(-4.37)\end{array}$ & $\begin{array}{c}-1.46 * * * \\
(-13.70)\end{array}$ & $\begin{array}{c}-0.408^{* * *} \\
(-3.18)\end{array}$ & $\begin{array}{l}-1.47 * * * \\
(-13.78)\end{array}$ & $\begin{array}{l}-0.333 \\
(-2.56)\end{array}$ & $\begin{array}{c}-1.514 * * * \\
(-13.96)\end{array}$ \\
\hline Control variables & No & Yes & No & Yes & No & Yes & No & Yes & No & Yes \\
\hline $\begin{array}{l}\text { Franked dividend } \\
\text { Included }\end{array}$ & No & No & No & No & No & No & No & No & No & No \\
\hline Industry Dummy & Yes & Yes & Yes & Yes & Yes & Yes & Yes & Yes & Yes & Yes \\
\hline Firm-years & 11174 & 10704 & 11174 & 10704 & 11174 & 10704 & 11174 & 10704 & 11174 & 10704 \\
\hline Number of firms & 1225 & 1207 & 1225 & 1207 & 1225 & 1207 & 1225 & 1207 & 1225 & 1207 \\
\hline Log likelihood & -3884.98 & -2353.9 & -3963.37 & -2357.65 & -3929.35 & -2366.5 & -3923.14 & -2367.65 & -3950.31 & -2367.04 \\
\hline Probability & 0.000 & 0.000 & 0.000 & 0.000 & 0.000 & 0.000 & 0.000 & 0.000 & 0.000 & 0.000 \\
\hline $\begin{array}{l}\text { Notes: } \\
\text { Dividend payout ratio (DP) refe } \\
\text { in Table } 1 \text {. The closer to } 6 \text { the } \\
1 \text {. The closer to } 3 \text { the better the } \\
\text { the governance. The variable de } \\
*, * *, * * * \text { denote significance at }\end{array}$ & $\begin{array}{l}\text { the percentage } \\
\text { BOD function } \\
\text { rnance. The } n \\
\text { ons for the con } \\
0 \%, 5 \% \text { and } 1\end{array}$ & ation and re & $\begin{array}{l}\text { It of net prof } \\
\text { ed governar } \\
\text { eration com } \\
\text { anked divide } \\
\text { y. }\end{array}$ & $\begin{array}{l}\text { The Board F } \\
\text { The audit } \mathrm{c} \\
\text { tee index (ci } \\
\text { are the same }\end{array}$ & $\begin{array}{l}\text { ory) is the su } \\
\text { in Table } 9 .\end{array}$ & ation of the & $\begin{array}{l}\text { ated by sumr } \\
\text { variables as } c\end{array}$ & ibed in Ta & $\begin{array}{l}\text { iables as d } \\
\text { 1. The clos }\end{array}$ & $\begin{array}{l}\text { as described } \\
\text { bed in Table } \\
2 \text { the better }\end{array}$ \\
\hline
\end{tabular}


The results in Table 9 show that the board of directors and audit committee (with less extent) is statistically significant regardless of model specifications. Remuneration and nomination committees are also positive but statistical significances are subject to model specifications.

Board function is closely associated with the board structure in our study as it is composed of board size, board meetings, independent of board of directors, CEO duality (separation of the role of chief executive officer and the board of directors' chairman), directors' shareholdings (percentage of shares held by the directors in the company), and CEO shareholdings (percentage of ordinary shares held by the CEO). As such, the finding in Table 10 illustrates that board function is determined by board composition and its activities are crucial to distribute dividend payouts.

The audit committee in this paper is composed of three governance variables, which includes the audit committee, the committee meeting at least once a year, and the existence of the one of the big four external auditors. Both board function and audit committee, vis-à-vis remuneration and nomination committee, are directly related to monitoring the manager's decisions and performance.

\subsection{Effect of Global Financial Crisis}

To examine any possible changing of dividend patterns during the financial crisis, this study adopted two different approaches. First, it included a binary variable for the Global Financial Crisis equal to one if years are subsets of 2007-2009, and zero otherwise. Second, it splits the sample into three sub-groups. The first one is before the onset of the Global Financial Crisis; the second and third occur during (2007-2009) and post- GFC.

Table 10: Tobit Estimation of the Effect of Corporate Governance Index I on Cash Dividend: The GFC effect

\begin{tabular}{ccc}
$\begin{array}{c}\text { Full sample } \\
(2001-2013)\end{array}$ & $\begin{array}{c}\text { Before the GFC } \\
(2001-2006)\end{array}$ & $\begin{array}{c}\text { During and after the } \\
\text { GFC } \\
(2007-2013)\end{array}$ \\
\hline
\end{tabular}




\begin{tabular}{|c|c|c|c|}
\hline & \multirow[b]{2}{*}{ Model 1} & \multirow[b]{2}{*}{ Mode 2} & \multirow[b]{2}{*}{ Model 3} \\
\hline & & & \\
\hline CG Index I & $\begin{array}{c}0.099 * * * \\
(2.59)\end{array}$ & $\begin{array}{c}0.145 * * * \\
(2.89)\end{array}$ & $\begin{array}{c}0.084^{*} \\
(1.65)\end{array}$ \\
\hline GFC & $\begin{array}{c}-0.066 * * * \\
(-3.04)\end{array}$ & & \\
\hline Firm Size & $\begin{array}{c}0.012 * * * \\
(2.66)\end{array}$ & $\begin{array}{c}0.011^{*} \\
(1.83)\end{array}$ & $\begin{array}{c}0.018 * * * \\
(2.84)\end{array}$ \\
\hline Profitability & $\begin{array}{c}0.648 * * * \\
(6.68)\end{array}$ & $\begin{array}{c}0.659 * * * \\
(5.12)\end{array}$ & $\begin{array}{c}0.624^{* * *} \\
(4.57)\end{array}$ \\
\hline Leverage & $\begin{array}{c}0.037^{* *} \\
(2.39)\end{array}$ & $\begin{array}{c}0.037^{*} \\
(1.85)\end{array}$ & $\begin{array}{c}0.039^{*} \\
(1.83)\end{array}$ \\
\hline Growth opportunities & $\begin{array}{c}-0.006^{*} \\
(-1.77)\end{array}$ & $\begin{array}{c}-0.008^{*} \\
(-1.92)\end{array}$ & $\begin{array}{l}-0.001 \\
(-0.39)\end{array}$ \\
\hline Firm Growth & $\begin{array}{c}-0.078 * * * \\
(-6.67)\end{array}$ & $\begin{array}{c}-0.090 * * * \\
(-6.10)\end{array}$ & $\begin{array}{c}-0.073 * * * \\
(-4.45)\end{array}$ \\
\hline Liquidity & $\begin{array}{c}-0.147^{* * *} \\
(-3.34)\end{array}$ & $\begin{array}{c}-0.192 * * * \\
(-3.20)\end{array}$ & $\begin{array}{c}-0.137^{* *} \\
(-2.39)\end{array}$ \\
\hline Financial Distress & $\begin{array}{c}-0.036 * * * \\
(-2.79)\end{array}$ & $\begin{array}{c}-0.031^{*} \\
(-1.86)\end{array}$ & $\begin{array}{c}-0.039 * * \\
(-2.24)\end{array}$ \\
\hline Dividend-track & $\begin{array}{c}0.227 * * * \\
(16.41)\end{array}$ & $\begin{array}{c}0.219 * * * \\
(11.70)\end{array}$ & $\begin{array}{c}0.212^{* * *} \\
(11.12)\end{array}$ \\
\hline Liquidity-test & $\begin{array}{c}-0.262 * * * \\
(-4.68)\end{array}$ & $\begin{array}{c}-0.227 * * * \\
(-2.60)\end{array}$ & $\begin{array}{c}-0.269^{* * * *} \\
(-4.04)\end{array}$ \\
\hline Franked dividend & $\begin{array}{c}0.035^{* *} \\
(2.24)\end{array}$ & $\begin{array}{c}0.069 * * * \\
(3.39)\end{array}$ & $\begin{array}{l}0.025 \\
(1.25)\end{array}$ \\
\hline Intercept & $\begin{array}{l}0.181 \\
(1.64)\end{array}$ & $\begin{array}{l}0.118 \\
(0.80)\end{array}$ & $\begin{array}{l}0.118 \\
(0.86)\end{array}$ \\
\hline $\begin{array}{l}\text { Industry /year } \\
\text { Dummy }\end{array}$ & Yes & Yes & Yes \\
\hline Firm-years & 3919 & 2176 & 2068 \\
\hline $\begin{array}{l}\text { Number of firms } \\
\text { Log likelihood }\end{array}$ & $\begin{array}{c}646 \\
-824.64\end{array}$ & $\begin{array}{c}521 \\
-512.2\end{array}$ & $\begin{array}{c}468 \\
-364.40\end{array}$ \\
\hline Probability & 0.000 & 0.000 & 0.000 \\
\hline
\end{tabular}

The estimated coefficient of the binary variable of GFC on Model 1 is negative, indicating that firms paid smaller dividends during the GFC than other years, as expected. This negative impact of the GFC on dividends was also confirmed by the change in estimated coefficient of the CGI from Model 2 to Model 3.

\subsection{Estimation using restricted sample periods}


As described above, the Australian corporate governance system has changed substantially since 2003. For this reason, we reran our model after splitting samples before and after 2003. Figures in Table 11 show qualitatively the same results as our main findings.

\begin{tabular}{|c|c|c|c|c|}
\hline & \multicolumn{2}{|c|}{$(2001-2003)$} & \multicolumn{2}{|c|}{$(2004-2013)$} \\
\hline & Model 1 & Model 2 & Model 3 & Model 4 \\
\hline CG Index I & $\begin{array}{c}0.191^{* *} \\
(2.42)\end{array}$ & $\begin{array}{c}0.260 * * * \\
(3.31)\end{array}$ & $\begin{array}{c}0.085^{* *} \\
(1.97)\end{array}$ & $\begin{array}{c}0.132 * * * \\
(3.06)\end{array}$ \\
\hline Firm Size & $\begin{array}{l}0.006 \\
(0.82)\end{array}$ & $\begin{array}{c}0.062 * * * \\
(7.58)\end{array}$ & $\begin{array}{c}0.015^{* * * *} \\
(2.91)\end{array}$ & $\begin{array}{c}0.066^{* * * *} \\
(11.86)\end{array}$ \\
\hline Profitability & $\begin{array}{c}0.844 * * * \\
(3.78)\end{array}$ & $\begin{array}{c}2.786 * * * \\
(12.23)\end{array}$ & $\begin{array}{c}0.579 * * * \\
(5.35)\end{array}$ & $\begin{array}{l}1.91 * * * \\
(19.17)\end{array}$ \\
\hline Leverage & $\begin{array}{c}0.093^{* * *} \\
(2.90)\end{array}$ & $\begin{array}{l}0.001 \\
(0.05)\end{array}$ & $\begin{array}{l}0.022 \\
(1.29)\end{array}$ & $\begin{array}{c}0.057 * * * \\
(3.28)\end{array}$ \\
\hline $\begin{array}{l}\text { Growth } \\
\text { opportunities }\end{array}$ & $\begin{array}{c}-0.015^{*} \\
(-1.94)\end{array}$ & $\begin{array}{c}-0.043^{* * *} \\
(-5.44)\end{array}$ & $\begin{array}{l}-0.002 \\
(-0.73)\end{array}$ & $\begin{array}{c}-0.019 * * * \\
(-5.15)\end{array}$ \\
\hline Firm Growth & $\begin{array}{c}-0.107 * * * \\
(-3.86)\end{array}$ & $\begin{array}{l}-0.026 \\
(-0.92)\end{array}$ & $\begin{array}{c}-0.065 * * * \\
(-5.11)\end{array}$ & $\begin{array}{c}-0.057 * * * \\
(-4.58)\end{array}$ \\
\hline Cash & $\begin{array}{l}0.029 \\
(0.28)\end{array}$ & $\begin{array}{c}0.069 \\
(-0.74)\end{array}$ & $\begin{array}{c}-0.183^{* * * *} \\
(-3.80)\end{array}$ & $\begin{array}{c}-0.154^{* * * *} \\
(-3.26)\end{array}$ \\
\hline Financial Distress & $\begin{array}{c}0.004 \\
(0.17)\end{array}$ & $\begin{array}{c}-0.066^{* *} \\
(-2.23)\end{array}$ & $\begin{array}{c}-0.043^{* * *} \\
(-3.05)\end{array}$ & $\begin{array}{c}-0.102^{* * *} \\
(-7.01)\end{array}$ \\
\hline Dividend-track & $\begin{array}{c}0.264 * * * \\
(8.41)\end{array}$ & $\begin{array}{c}0.551^{* * * *} \\
(16.23)\end{array}$ & $\begin{array}{c}0.223^{* * *} \\
(14.39)\end{array}$ & $\begin{array}{c}0.430 * * * \\
(24.91)\end{array}$ \\
\hline Liquidity-test & $\begin{array}{l}-0.034 \\
(-0.19)\end{array}$ & $\begin{array}{l}0.119 \\
(0.98)\end{array}$ & $\begin{array}{c}-0.308 * * * \\
(-5.29)\end{array}$ & $\begin{array}{c}-0.120 * * \\
(-2.41)\end{array}$ \\
\hline Franked dividend & $\begin{array}{c}0.068^{* *} \\
(2.17)\end{array}$ & & $\begin{array}{c}0.031^{*} \\
(1.80)\end{array}$ & \\
\hline Intercept & $\begin{array}{l}-0.190 \\
(-0.75)\end{array}$ & $\begin{array}{c}-1.888 * * * \\
(-8.94)\end{array}$ & $\begin{array}{l}0.162 \\
(1.38)\end{array}$ & $\begin{array}{c}-1.335 * * * \\
(-11.45)\end{array}$ \\
\hline Industry Dummy & Yes & Yes & Yes & Yes \\
\hline Firm-years & 887 & 2504 & 3032 & 8200 \\
\hline Number of firms & 384 & 914 & 558 & 1105 \\
\hline Log likelihood & -286.94 & -657.25 & -547.31 & -1700.13 \\
\hline Probability & 0.000 & 0.000 & 0.000 & 0.000 \\
\hline
\end{tabular}

\section{Conclusion}

This study investigates the effect of corporate governance on the dividend policy of Australian firms over the period of 2001-2013. To capture multiple aspects of corporate 
governance, this paper calculated governance indexes. The main index is based on thirteen governance variables, which are divided into four categories.

Random effect panel Tobit estimation results support a positive relation between governance quality and dividend payouts. Firms with better corporate governance mechanism will pay higher dividends to reduce agency problems. These results can also support the complementary role of corporate governance and dividend payout policy of the firms in Australia. The dividend was also positively affected by the franked dividend system. In contrast, growth opportunities constrained dividend distribution, which is in line with the life cycle hypothesis.

Further analyses show the intensifying effect of governance on dividends by the level of franked dividends. This finding suggests that the effect of governance on dividend differs depending on the corporate tax system. In contrast, the positive effect of governance on dividends was attenuated by growth opportunities. This finding suggests firms value cash and liquidity differently depending on their life cycle and availability of profitable projects.

Further investigation, using each individual governance element, shows that the board function and audit committee, vis-à-vis numeration and nomination committees, are more important for determining dividend payouts. The estimation result also shows the negative effect of the GFC on dividend payout.

In addition to the managerial implications described above, our findings provide some policy implications. First, our results illustrate the importance of a proper arrangement of institutional settings to improve fairness and equity in an economy. That is, well-functioning corporate governance is a way to strengthen the rights of minority shareholders by preventing managerial private consumption. Second, both the agency theory and our findings suggest that improved corporate governance is also important for allocative efficiency of resources as good governance can reduce 'waste' of 'free' cash flows. Third, however, it is uncertain 
whether the franked dividends motivate investors to expect more dividend payouts than the optimum level of payouts as indicated by the agency theory.

\section{Notes}

1. Following the major corporate collapses in the U.S. (e.g., Enron in 2001, WorldCom in2002 and Adelphia communications in 2002), Europe and Australia (for example, Ansett Airline in 2001, Haris Scarfe in 2001 and HIH in 2001), corporate governance systems have received much more attention. Policy makers have improved on their previous policies and developed new policies in order to reestablish investors' confidence in those countries. An effective corporate governance structure through policy reforms is expected to increase corporate value by improved accountability and control systems commensurate with the risks involved.

Following the high rate of corporate collapse in the 1980s and early 1990s in Australia, four major business organizations which include the Australian Stock Exchange, the Business Council of Australia, the Institute of Chartered Accountants and the Institute of Directors in Australia, approached the chairman of the National Companies and Securities commission, Henry Bosch, and discussed the increased concern of the public-related corporate governance. Following their discussion, Bosch (1993) published a set of guidelines titled "Corporate practices and conduct". The guidelines were then revised in 1995. In 1997, the ASX released a set of guidelines titled "Good response to ASX Corporate Governance Disclosure rules.” The ASX announced in the media that every one of the largest 150 companies listed in the Australian Stock Exchange complied with new listing rule.

Australian corporate governance mechanisms were also developed by the Investor and Financial Services Association Limited (IFSA). The first edition of the IFSA guidelines for corporate governance practices, particularly for investment managers, was published in 1995 with the title of "Corporate Governance: a guide for investment managers and a statement of recommended corporate practices.” The guideline was updated in following years, including July 1997(2nd edition), July 1999 (3rd edition), December 2002 (4th edition), October 2004 (5th edition) and June 2009 (6th edition).

One of the most comprehensive corporate governance guidelines was drawn up by the ASX Corporate Governance Council (2003) with the title of Principles of Good Corporate Governance and Best Practice Recommendations. The review consisted of 10 principles and 28 recommendations applicable to the corporate governance practices for the companies listed on the Australian Stock Exchange. The guideline was later revised in (2007) and (2010). 
2. The major changes include: dividends cannot be paid by companies unless all of the following requirements are met; the assets of a company exceeded its liabilities immediately before the dividend is declared and the exceed is sufficient for dividend payment; the amount of dividend is reasonable and fair for the company's shareholders as whole; and the dividend payment does not materially prejudice the company ability to pay its creditors.

3. The theory incorporates components of agency theory (Jensen and Meckling 1976, Jensen 1986) with progression in the investment opportunities of the firm, which was also discussed by Fama and French (2001) and Grullon et al. (2002). 


\begin{tabular}{|c|c|c|}
\hline Variables & $\begin{array}{c}\text { ASX Recommendation } \\
\text { (2003) }\end{array}$ & Theory and evidence \\
\hline Board size & $\begin{array}{l}\text { Principle 2- } \\
\text { Structure the board to } \\
\text { add value-Companies } \\
\text { should have a board of } \\
\text { an effective } \\
\text { composition, size and } \\
\text { commitment to } \\
\text { adequately discharge its } \\
\text { responsibilities and } \\
\text { duties. }\end{array}$ & $\begin{array}{l}\text { Larger boards can bring more experience and recourse to } \\
\text { the firm and are more constructive for firm performance } \\
\text { (Dalton, et al., 1999). Chiang (2005) and Haniffa and } \\
\text { Hudaib (2006) also show that board size is significantly } \\
\text { associated with accounting and market performance. } \\
\text { Similarly, Bokpin (2011) and Chen and Yong-Cheol } \\
\text { (2011) show the positive relationship between the size of } \\
\text { the board and the propensity of companies to pay cash } \\
\text { dividends. This study argues that larger boards have more } \\
\text { specialized skills and are better equipped to monitor } \\
\text { managers (Williams et al., 2005). They are therefore more } \\
\text { effective and have a positive influence on a firm's } \\
\text { dividend policy. }\end{array}$ \\
\hline $\begin{array}{l}\text { Board } \\
\text { meeting }\end{array}$ & & $\begin{array}{l}\text { Lipton and Lorsch (1992) suggested that one of the most } \\
\text { widely shared problems among directors is a lack of time } \\
\text { to carry out their tasks. Likewise, Conger et al. (1998) } \\
\text { suggested that directors can increase board effectiveness } \\
\text { by increasing the number of times the board meets. } \\
\text { Similarly, Vafeas (1999) showed a positive relationship } \\
\text { among board meeting frequency, corporate governance } \\
\text { and ownership characteristics that was consistent with } \\
\text { contracting and agency theory. Additionally, Kent and } \\
\text { Stewart (2008) suggested that boards of directors need to } \\
\text { be active to meet their corporate governance commitments, } \\
\text { particularly in ensuring high-quality, transparent reporting } \\
\text { in annual reports. This study argues that companies with } \\
\text { more frequent board meetings are more likely to perform } \\
\text { their duties diligently and effectively, thereby enhancing } \\
\text { their level of oversight (Yatim et al., 2006) and having a } \\
\text { positive effect on a firm's dividend policy }\end{array}$ \\
\hline $\begin{array}{l}\text { Directors } \\
\text { Independence }\end{array}$ & $\begin{array}{l}\text { Recommendation 2.1: } \\
\text { A majority of the board } \\
\text { should be independent. }\end{array}$ & $\begin{array}{l}\text { Directors' independence also has a large effect on firm } \\
\text { performance and consequently on dividend policy } \\
\text { decisions. According to stewardship theory, less } \\
\text { independent boards are expected to be highly associated } \\
\text { with better performance. Anderson (2004) and Weisbach } \\
\text { (1988) showed a significant and positive relationship } \\
\text { between the proportion of outsiders on a board and firm } \\
\text { performance. Dahya and McConnel (2007) also showed } \\
\text { that firms with a higher percentage of independent } \\
\text { directors have higher market valuations. This study argues } \\
\text { that independent directors can positively affect dividend } \\
\text { policy because they are in a better position to protect } \\
\text { shareholders' interests from opportunistic managers } \\
\text { (because they are they are independent from managers' } \\
\text { influence) (Fama and Jensen, 1983). }\end{array}$ \\
\hline
\end{tabular}


Appendix I: Governance Index Development (Continued)

$\begin{array}{ccc}\text { Variables } & \text { ASX Recommendation } & \text { Theory and evidence }\end{array}$

Directors'

shareholding

CEOs'

shareholding

Chairman

and CEO

separation
Recommendation 2.3: The roles of the chairperson and chief executive officer should not be held by the same individual.

\begin{tabular}{ll}
\hline Audit & Recommendation 4.2: \\
Committee & The board should \\
& establish an audit \\
& committee.
\end{tabular}

Welch's (2003) study of Australian listed companies indicated a significant relationship between managerial ownership and firm performance. The results also show that when endogeneity is taken into account, ownership and performance measures are not significantly dependent. Similarly, Wruck (1989) showed a significant and positive relationship between concentrated ownership and firm performance. Fenn and Liang (2001) showed that in a mature market, managers' stock ownership can result in higher dividend payments by better aligning the interests of shareholders and management. In this study we consider higher share ownership among directors and CEOs to have a positive effect on dividend policy as the interests of managers and general shareholders will be the same. Therefore, we considered the Directors, and CEOs who have more than $5 \%$ to have influence and a positive effect on Dividend payouts

The final criterion of board structure is CEO duality. Previous studies indicated that most CEOs are opportunistic and therefore not automatically loyal to their shareholders (Jensen, 1986, 1993; Morck et al., 1990; Shleifer and Vishny, 1989, 1997); therefore, they prefer to use money for their personal goals rather than paying dividends to shareholders. CEO Chairperson Duality can occur when the Chief Executive Officer (CEO) of the firm also serves as a chairperson of the board. In the perspective of agency theory, there is near consensus that one individual should not perform the roles of board chairperson and CEO simultaneously (Zahra and Pearce, 1989; Lehn and Zhao, 2006). This study argues that companies that separate the role of CEO and chairman have better performance and can make better decisions concerning their dividend policy.

The audit committee performs an important role in monitoring the board's fulfilment of its corporate governance and oversight responsibilities in relation to a company risk management system, internal control system, financial reporting and internal and external audit functions. An effective audit committee is a salient feature of a sound corporate governance system (DeZoort and Salterio, 2001). This study argues that the existence of an independent audit committee and committees with at least one meeting annually can positively affect dividend policy. 


\begin{tabular}{|c|c|c|}
\hline Variables & $\begin{array}{c}\text { ASX } \\
\text { Recommendation } \\
\text { (2003) }\end{array}$ & Theory and evidence \\
\hline $\begin{array}{l}\text { External } \\
\text { Auditor }\end{array}$ & & $\begin{array}{l}\text { External auditors are in a position to ensure that companies } \\
\text { are aware of new reporting requirements (Kent and Stewart, } \\
\text { 2008). Audit firms generally have more resources and } \\
\text { experience to ensure that they are familiar with new } \\
\text { accounting requirements. It is also assumed that these } \\
\text { accounting firms have a greater incentive to protect their } \\
\text { reputation because of their larger client base (Francis and } \\
\text { Krishnan, 1999; Francis et al., 1999; Krishnan, 2003; Kim et } \\
\text { al., 2003). As a result, they are more conservative and require } \\
\text { a greater level of disclosure (Clarkson et al., 2003). The Big } \\
\text { Six accounting firms are more likely to ensure transparency } \\
\text { and eliminate mistakes in financial statements because they } \\
\text { are more professional and have a greater reputation to uphold } \\
\text { (Michaely and Shaw, 1995). Disclosure is improved if the } \\
\text { firm's external auditor is one of the big six international } \\
\text { accountant firms (Fan and Wong, 2005). Since the merging of } \\
\text { the big six companies, we will consider the big four audit } \\
\text { firms to have a positive effect on dividend policy. }\end{array}$ \\
\hline $\begin{array}{l}\text { Nomination } \\
\text { committee }\end{array}$ & $\begin{array}{l}\text { Recommendation } \\
\text { 2.4: The board } \\
\text { should establish a } \\
\text { nomination } \\
\text { committee. }\end{array}$ & $\begin{array}{l}\text { The nomination committee focuses on assessing the board of } \\
\text { directors and examining the characteristics and skills that are } \\
\text { required in the board candidates, and should therefore be } \\
\text { separate from the board. A nominating committee provides } \\
\text { independent recommendations and opinions for choosing the } \\
\text { best board candidates. In addition, its existence indicates a } \\
\text { formal and transparent process for the re-appointment of } \\
\text { existing directors and new directors (Singapore Code of } \\
\text { Corporate of Governance 2001). This study therefore argues } \\
\text { that the existence of nomination committee, and the } \\
\text { committee having at least one meeting annually can positively } \\
\text { effect on dividend policy }\end{array}$ \\
\hline $\begin{array}{l}\text { Remuneration } \\
\text { committee. }\end{array}$ & $\begin{array}{l}\text { Recommendation } \\
\text { 9.2: The board } \\
\text { should establish a } \\
\text { remuneration } \\
\text { committee. }\end{array}$ & $\begin{array}{l}\text { Rumination committees appoint and review the amount and } \\
\text { nature of all remuneration for senior officers of the company. } \\
\text { This contributes to alleviating the agency problem by } \\
\text { designing, constructing and implementing incentive schemes } \\
\text { to better align the goals between management and } \\
\text { shareholders (Jensen and Murphy, 1990). A separate } \\
\text { remuneration committee plays a key role in determining that } \\
\text { remuneration policies are effective and reported and explained } \\
\text { to the shareholders. In the absence of an independent } \\
\text { remuneration committee, it appears that executives are } \\
\text { allowed to write their own contracts with one hand and sign } \\
\text { them with the other (Williamson, 1988). This study therefore } \\
\text { argues that the existence of remuneration committee, and the } \\
\text { committee having at least one meeting annually can positively } \\
\text { affect dividend policy }\end{array}$ \\
\hline
\end{tabular}




\section{References}

Adjaoud, F. and Ben-Amar, W. (2010), “Corporate governance and dividend policy: shareholders' protection or expropriation?”, Journal of business finance \& accounting, Vol. 37 Nos 5-6, pp. 648-667.

Aggarwal, R., Erel, I., Ferreira, M. and Matos, P. (2011), “Does governance travel around the world?: Evidence from institutional investors”, Journal of financial economics, Vol. 100 No. 1, pp. 154-181.

Anderson, R.C. and Reeb, D.M. (2004), "Board composition: balancing family influence in S\&P 500 firms", Administrative Science Quarterly, Vol. 49 No. 2, pp. 209-237

ASX Corporate Governance Council (2003), Principle of Good Corporate Governance and Best Practice Recommendations , Sydney: ASX.

Beekes, W. and Brown, P. (2006), “Do better governed Australian girms make more informative disclosures?”, Journal of Business Finance and Accounting, Vol. 33 No. 4, pp. 422-450.

Bellamy, D.E. (1994), “Evidence of imputation clienteles in the Australian equity market”, Asia Pacific Journal of Management”, Vol. 11 No. 2, pp. 275-287.

Bokpin, G. (2011), “Ownership structure, corporate governance and dividend performance on the Ghana Stock Exchange”, Journal of Applied Accounting Research, Vol. 12 No. 1, pp. 61-73.

Bosch, H. (1993), “Corporate practices and conduct: setting standards for corporate governance in Australia”, Corporate Governance: An International Review, Vol. 1 No. 4, pp. 196-198.

Brown, L.D. and Caylor, M.L. (2006), “Corporate governance and firm valuation”, Journal of accounting and public policy, Vol. 25 No. 4, pp. 409-434.

Brown, P. and Clarke, A. (1993), “The ex-dividend day behaviour of Australian share prices before and after dividend imputation”, Australian Journal of Management, Vol. 18 No. 1, pp. 1-40.

Chan, M.C., Watson, J. and Woodliff, D. (2014), “Corporate covernance quality and CSR disclosures”, Journal of Business Ethics, Vol. 125 No. 1, pp. 59-73.

Chen, L., Lin, C. and Yong-Cheol, K. (2011), "Financial characteristics, corporate governance and the propensity to pay cash dividends of Chinese listed companies”, International Business and Management, Vol. 3 No. 1, pp. 176-188.

Chiang, H.T. (2005), “An empirical study of corporate governance and corporate performance”, Journal of American Academy of Business, Vol. 6 No. 1, pp. 95-101.

Christensen, J., Kent, P. and Stewart, J. (2010), “Corporate governance and company performance in Australia”, Australian Accounting Review, Vol. 20 No. 4, pp. 372-386. 
Clarkson, P.M., Ferguson, C. and Hall, J. (2003), “Auditor conservatism and voluntary disclosure: Evidence from the year 2000 systems issue”, Accounting and Finance, Vol. 43 No. 1, pp. 21-40.

Conger, J.A., Finegold, D. and Lawler III, E. (1998), “Appraising boardroom performance”, Harvard business review, Vol. 76 No. 1, pp. 136-148.

Coulton, J.J. and Ruddock, C. (2011), “Corporate payout policy in Australia and a test of the life-cycle theory”, Accounting \& Finance, Vol. 51 No. 2, pp. 381-407.

Crutchley, C.E. and Hansen, R.S. (1989), “A test of the agency theory of managerial ownership, corporate leverage and corporate dividends”, Financial Management, Vol. 18 No. 4, pp. 36-46.

Dahya, J. and McConnell, J.J. (2007), "Board composition, corporate performance, and the cadbury committee recommendation”, Journal of Financial and Quantitative Analysis, Vol. 42 No. 3, pp. 535-564.

Dalton, D., Daily, C., Johnson, J. and Ellstrand, A. (1999), "Number of directors and financial performance: A meta-analysis”, Academy of Management Journal, Vol. 42 No. 6, pp. 674-686.

Damodaran, A. (1999), Applied Corporate Finance, New York: John Wiley\& Son, Inc.

DeAngelo, H. and DeAngelo, L. (2006), “The irrelevance of the MM dividend irrelevance theorem”, Journal of Financial Economics, Vol. 79 No. 2, pp. 293-316.

DeAngelo, H., DeAngelo, L. and Skinner, D. (1992), “Dividends and losses”, The Journal of Finance, Vol. 47 No. 5, pp. 1837-1863.

DeAngelo, H., DeAngelo, L. and Stulz, R.M. (2006), "Dividend policy and the earned/contributed capital mix: A test of the life-cycle theory”, Journal of financial economics, Vol. 81 No. 2, pp. 227-254.

DeZoort, F.T. and Salterio, S.E. (2001), “The effects of corporate governance experience and financial-reporting and audit knowledge on audit committee members' judgments”, Auditing: A Journal of Practice \& Theory, Vol. 20 No. 2, pp. 31-47.

Easterbrook, F.H. (1984), “Two agency-cost explanations of dividends”, The American Economic Review, Vol. 74 No. 4, pp. 650-659.

Fama, E.F. and Jensen, M.C. (1983), “Separation of ownership and control”, The Journal of Law and Economics, Vol. 26 No. 2, pp. 301-325.

Fama, E. and French, K. (2001), "Disappearing dividends: changing firm characteristics or lower propensity to pay?”, Journal of Financial Economics, Vol. 60 No. 1, pp. 3-43.

Fan, O.P.H. and Wong, T. J. (2005), "Do external auditors perform a corporate governance role in emerging markets? evidence from east Asia”, Journal of Accounting Research, Vol. 43 No. 1, pp. 35-72.

Farinha, J. (2003), “Dividend policy, corporate governance and the managerial entrenchment hypothesis: An empirical analysis”, Journal of Business Finance \& Accounting, Vol. 30 Nos 9-10, pp. 1173-1209. 
Fenn, G.W. and Liang, N. (2001), “Corporate payout policy and managerial stock incentives”, Journal of financial economics, Vol. 60 No. 1, pp. 45-72.

Francis, J.R., Maydew, E.L. and Sparks, H.C. (1999), "The role of big 6 auditors in the credible reporting of accruals”, A Journal of Practice and Theory, Vol. 18 No. 2, pp. 17-34.

Francis, B.B., Hasan, I., John, K. and Song, L. (2011), “Corporate governance and dividend payout policy: a test using antitakeover legislation”, Financial Management, Vol. 40 No. 1, pp. 84-112.

Francis, J.R. and Krishnan, J. (1999), “Accounting accruals and auditor reporting conservatism”, Contemporary Accounting Research, Vol. 16 No. 1, pp. 135-165.

Gompers, P., Ishii, J. and Metrick, A. (2003), “Corporate governance and equity prices”, The Quarterly Journal of Economics, Vol. 118 No. 1, pp. 107-112.

Greene, W.H. (2003), Econometric Analysis 5th. s.l.:Upper Saddle River, N.J: Prentice Hall.

Grullon, G., Michaely, R. and Swaminathan, B. (2002), “Are dividend changes a sign of firm maturity”, Journal of Business, Vol. 75 No. 3, p. 387-424.

Haniffa, R. and Hudaib, M. (2006), “Corporate governance structure and performance of Malaysian listed companies”, Journal of Business Finance \& Accounting, Vol. 33 No. 7, pp. 1034-1062.

Henry, D. (2011), “Ownership structure and tax-friendly dividends”, Journal of banking \& finance, Vol. 35 No. 10, pp. 2747-2760.

Jensen, M.C. (1986), “Agency cost of free cash flow, corporate finance, and takeovers”, American Economic Review, Vol. 76 No. 2, pp. 323-329.

Jensen, M.C. (1993), “The modern industrial revolution, exit, and the failure of internal control systems”, The Journal of Finance, Vol. 48 No. 3, pp. 831-880.

Jensen, M.C. and Meckling, W.H. (1976), "Theory of the firm: managerial behavior, agency costs and ownership structure”, Journal of Financial Economics, Vol. 3 No. 4, pp. 305-360.

Jensen, M.C. and Murphy, K.J. (1990), “Performance pay and top management Incentives”, Journal of Political Economy, Vol. 98 No. 2, pp. 225-264.

Jiraporn, P., Kim, J.-C. and Kim, Y.S. (2011), “Dividend payouts and corporate governance quality: An empirical investigation”, Financial Review, Vol. 46 No. 2, pp. 251-279.

Jiraporn, P., Kim, J.C., Kim, Y.S. and Kitsabunnarat, P. (2012), “Capital structure and corporate governance quality: evidence from the institutional shareholder services (ISS)”, International Review of Economics and Finance, Vol. 22 No. 1, pp. 208-221.

Kent, P. and Stewart, J. (2008), “Corporate governance and disclosures on the transition to international financial reporting standards”, Accounting and Finance, Vol. 48 No. 4, pp. 649-671. 
Kim, J.B., Chung, R. and Firth, M. (2003), “Auditor conservatism, asymmetric monitoring, and earnings management”, Contemporary Accounting Research, Vol. 20 No. 2, pp. 323-359.

Kim, B. and Maddala, G.S. (1992), "Estimation and specification analysis of models of dividends behavior based on censored panel data”, Empirical Economics, Vol. 17 No. 1, pp. 111-124.

Krishnan, G.V. (2003), “Does big 6 auditor industry expertise constrain earnings management?”, Accounting Horizons, Vol. 17 No. 1, pp. 1-16.

La Porta, R., Shleifer, A. and Vishny, R.W. (2000), “Agency problems and dividend policy around the world”. The Journal of Finance, Vol. 55 No. 1, pp. 1-33.

Lehn, K.M. and Zhao, M. (2006), “CEO turnover after acquisitions: do bad bidders get fired?”, Journal of Finance, Vol. 61 No. 4, p. 1759-1811.

Linden, P. and Matolcsy, Z. (2004), “Corporate governance scoring systems: what do they tell us?”, Australian Accounting Review, Vol. 14 No. 1, pp. 9-16.

Lipton, M. and Lorsch, J., (1992), “A modest proposal for improved corporate governance”, Business lawyer, Vol. 48 No. 1, pp. 59-77.

Michaely, R. and Shaw, W.H. (1995), “Does the choice of auditor convey quality in an initial public offering?”, Financial Management, Vol. 24 No. 4, pp. 15-30.

Miller, M.H. and Modigliani, F. (1961), “Dividend policy, growth, and the valuation of shares”, The Journal of Business, Vol. 34 No. 4, pp. 411-433.

Mitton, T. (2004), “Corporate governance and dividend policy in emerging markets”, Emerging Markets Review, Vol. 5 No. 4, pp. 409-426.

Monem, R.M. (2013), “Determinants of board structure: evidence from Australia”, Journal of contemporary accounting \& economics, Vol. 9 No. 1, pp. 33-49.

Monkhouse, P.H. (1993), “The cost of equity under the Australian dividend imputation tax system”, Accounting and Finance, Vol. 33 No. 2, pp. 1-18.

Morck, R., Shleifer, A. and Vishny, R. W. (1990), “Do managerial objectives drive bad acquisitions?”, The Journal of Finance, Vol. 45 No. 1, pp. 31-48.

Myers, S.C. and Majluf, N.S. (1984), “Corporate financing and investment decisions when firms have information that investors do not have”, Journal of Financial Economics, Vol. 13 No. 2, pp. 187-221.

Nenova, T. (2003), “The value of corporate voting rights and control: a cross-country analysis”, Journal of financial economics, Vol. 68 No. 3, pp. 325-351.

Pattenden, K. and Twite, G. (2008), “Taxes and dividend policy under alternative tax regimes”, The journal of corporate finance, Vol. 14 No. 1, pp. 1-16. 
Prommin, P., Jumreornvong, S. and Jiraporn, P. (2014), “The effect of corporate governance on stock liquidity: The case of Thailand”, International Review of Economics and Finance, Vol. 32 No. 7, pp. 132-142.

Rediker, K.J. and Seth, A. (1995), "Boards of directors and substitution effects of alternative governance mechanisms”, Strategic Management Journal, Vol. 16 No. 2, pp. 85-99.

Rozeff, M.S. (1982), “Growth, beta and agency costs as determinants of dividend payout ratios”, Journal of Financial Research, Vol. 5 No. 3, pp. 249-259.

Sawicki, J. (2009), “Corporate governance and dividend policy in Southeast Asia pre- and post-crisis”, European Journal of Finance, Vol. 15 No. 1, pp. 211-230.

Setia-Atmaja, L., Tanewski, G.A. and Skully, M. (2009), "The role of dividends, debt and board structure in the governance of family controlled firms”, Journal of business finance \& accounting, Vol. 36 Nos 7-8, pp. 863898.

Shleifer, A. and Vishny, R.W. (1989), “Management entrenchment: The case of manager specific investments”, Journal of Financial Economics, Vol. 25 No. 1, pp. 123-139.

Shleifer, A. and Vishny, R.W. (1997), “A survey of corporate governance”, The Journal of Finance, Vol. 52 No. 2, pp. 737-783.

Smith, C.W. (1992), “The investment opportunity set and corporate financing, dividend, and compensation policies”, Journal of financial economics, Vol. 32 No. 3, pp. 363-392.

Vafeas, N. (1999), “Board meeting frequency and firm performance”, Journal of Financial Economics, Vol. 53 No. 1, pp. 113-142.

Weisbach, M. (1988), “Outside directors and CEO turnover”, Journal of Financial Economics, Vol. 20 No. 1, pp. 431-460.

Welch, E. (2003), "The relationship between ownership structure and performance in listed Australian companies”, Australian Journal of Management, Vol. 28 No. 3, pp. 287-305.

Williamson, O.E. (1988), “Corporate finance and corporate governance”, The Journal of Finance, Vol. 43 No. 3 , pp. 567-591.

Williams, R.J., Fadil, P.A. and Armstrong, R.W. (2005), “Top management team tenure and corporate illegal activity: The moderating influence of board size”, Journal of Managerial Issues, Vol. 17 No. 4, pp. 479-493.

Wruck, K.H. (1989), “Equity ownership concentration and firm value”, Journal of Financial Economics, Vol. 23 No. 1, pp. 3-28.

Yarram, S.R. (2015), “Corporate governance ratings and the dividend payout decisions of Australian corporate firms”, International Journal of Managerial Finance, Vol. 11 No. 2, pp. 162-178. 
Yarram, S.R. and Dollery, B. (2015), "Corporate governance and financial policies: Influence of board characteristics on the dividend policy of Australian firms”, Managerial Finance, Vol. 41 No. 3, pp. 267-285.

Yatim, P., Kent, P. and Clarkson, P. (2006), "Governance structures, ethnicity, and audit fees of Malaysian listed firms”, Managerial Auditing Journal, Vol. 21 No. 7, pp. 757-782.

Zahra, S.A. and Pearce, J.A. (1989), "Boards of directors and corporate financial performance: A review and integrative model”, Journal of Management, Vol. 15 No. 2, pp. 291-334. 